\title{
Recruitment of $\gamma \delta$ T cells to the lesion via the CCL2/CCR2 signaling after spinal cord injury
}

Ping $\mathrm{Xu}^{1}$, Feng Zhang ${ }^{2}$, Min-min Chang ${ }^{3}$, Cheng Zhong ${ }^{4}$, Cheng-Hong Sun ${ }^{5}$, Hao-Ran Zhu' ${ }^{1}$ Jing-Chun Yao ${ }^{5}$, Zhi-Zhong Li ${ }^{1,6}$, Si-Tao Li $i^{7^{*}}$, Wen-Cai Zhang ${ }^{1 *}$ and Guo-Dong Sun ${ }^{1^{*}}$ (D)

\begin{abstract}
Background: Immune cell infiltration and neuroinflammation are heavily associated with spinal cord injury (SCI). CC motif chemokine ligand 2/C-C chemokine receptor type 2 (CCL2/CCR2) axis has been identified as a critical role player during the invasion of immune cells to lesions in many diseases. $\gamma \delta T$ cells, a subgroup of $T$ cells, manage the course of inflammation response in various diseases; however, it remains unknown whether $\gamma \delta T$ cells are recruited to injury site through CCL2/CCR2 signaling and exert the regulation effect on neuroinflammation after SCI.

Methods: Basso Mouse Scale (BMS), regularity index, cadence, max contact area, and motor-evoked potential testing (MEP) were measured to determine the neurological function recovery after spinal cord injury. Nissl staining was performed to identify the number of surviving motor neurons at lesion epicenter. Immunofluorescence, Western blot, enzyme-linked immunosorbent assays (ELISA), and quantitative real-time polymerase chain reaction (QRT-PCR) also were employed to evaluate the expression of associated proteins and genes.

Results: In this study, we demonstrated that $\mathrm{TCR}^{-/-}$mice present improved neurological recovery after SCI. $\gamma \delta \mathrm{T}$ cell recruitment to the $\mathrm{SCl}$ site was significantly reduced and motor functional improvement enhanced in $\mathrm{CCL}^{-/-}$ and $\mathrm{CCR}^{-/-}$mouse strains. Furthermore, reconstitution of $\mathrm{TCR}^{-/-}$mice with $\gamma \delta \mathrm{T}$ cells extracted from $\mathrm{CCR}^{-/-}$ mice also showed similar results to CCL2 and CCR2 deficient mice.

Conclusions: In conclusion, $\gamma \delta$ T cell recruitment to $\mathrm{SCl}$ site promotes inflammatory response and exacerbates neurological impairment. CCL2/CCR2 signaling is a vital recruitment mechanism of $\gamma \delta$ T cells to the $S C l$ site, and it may be taken as a novel therapeutic target for future SCl.
\end{abstract}

Keywords: Spinal cord injury, Inflammation, $\gamma \delta$ T cell, CCL2, CCR2

\footnotetext{
*Correspondence: lisit@mail.sysu.edu.cn; zhwc50@sohu.com; sgd96@jnu.edu.cn

${ }^{7}$ Department of Pediatrics, The Sixth Affiliated Hospital, Sun Yat-sen

University, No. 26 Yuancun Erheng Road, Tianhe District, Guangzhou 510655,

China

'Department of Orthopedics, The First Affiliated Hospital of Jinan University,

601 West Whampoa Avenue, Guangzhou 510000, China

Full list of author information is available at the end of the article
}

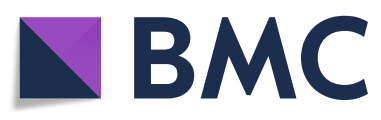

(c) The Author(s). 2021 Open Access This article is licensed under a Creative Commons Attribution 4.0 International License, which permits use, sharing, adaptation, distribution and reproduction in any medium or format, as long as you give appropriate credit to the original author(s) and the source, provide a link to the Creative Commons licence, and indicate if changes were made. The images or other third party material in this article are included in the article's Creative Commons licence, unless indicated otherwise in a credit line to the material. If material is not included in the article's Creative Commons licence and your intended use is not permitted by statutory regulation or exceeds the permitted use, you will need to obtain permission directly from the copyright holder. To view a copy of this licence, visit http://creativecommons.org/licenses/by/4.0/ The Creative Commons Public Domain Dedication waiver (http://creativecommons.org/publicdomain/zero/1.0/) applies to the data made available in this article, unless otherwise stated in a credit line to the data. 


\section{Introduction}

Spinal cord injury (SCI) can cause neurological dysfunctions such as irreversible loss of sensory and motor functions below individual injury levels [1]. Moreover, it is characterized by high rates of morbidity and disability, which to a large extent, increase the difficultly of treatment for SCI [2]. Although the treatment of SCI involves general measures such as resuscitation, and specific treatment that also varies between early and late and that related to the insult itself or consequence/complications, the clinical efficiency of those measures is very limited $[3,4]$. We, therefore, need to urgently perform further research on the pathological mechanism of SCI for developing more effective treatments.

The pathological progression of SCI is divided into two parts: primary injury and secondary injury. The primary injury refers to mechanical injuries to local tissues and vessels including compression, contusion, and stretch and tear [5]. In addition, the primary injury can induce inflammatory immune responses that are closely associated with the secondary injury. Inflammation increases the permeability of the blood-spinal cord barrier, further facilitating the infiltration of peripheral immune cells such as $\gamma \delta$ T cells and macrophages to the injury site, thus adding to the existing aggravated damage. $\gamma \delta \mathrm{T}$ cells represent a subset of $\mathrm{T}$ cells that mainly exist in mucous membranes, skin, and adipose tissue. Moreover, they are MHC-unrestricted innate-like lymphocytes with unique antigen receptors, and play a vital role in innate and immune responses [6, 7]. In addition, $\gamma \delta \mathrm{T}$ cells not only respond quickly to infection or inflammation but also promote secretion of IFN- $\gamma$, IL-17, and IL-23 that might seriously influence the outcome of central nervous system diseases [8]. Our previous study showed that $\gamma \delta$ $\mathrm{T}$ cells were recruited to the lesion as a main source of IFN- $\gamma$ in the early stage after SCI, which induced macrophage polarization into M1 phenotype, released proinflammatory cytokines, and further hampered recovery of the injury cord [4]. However, the mechanism by which $\gamma \delta \mathrm{T}$ cells migrate to the site of SCI is still unknown.

C-C motif chemokine ligand 2 (CCL2/MPC-1) is a chemokine that recruits immune cells to inflammatory site through blinding to $\mathrm{C}-\mathrm{C}$ chemokine receptor type 2 (CCR2) [9]. A recent study demonstrated that CCX872, a selective CCR2 antagonist, could decrease the accumulation of M1-type macrophages, and further improve the cognitive dysfunction caused by traumatic brain injury [10]. Both CCR2 and CCR6 are expressed on the surface of $\gamma \delta \mathrm{T}$ cells and can efficiently regulate the directional migration of $\gamma \delta \mathrm{T}$ cells. However, under inflammatory conditions, the expression of CCR6 is downregulated,

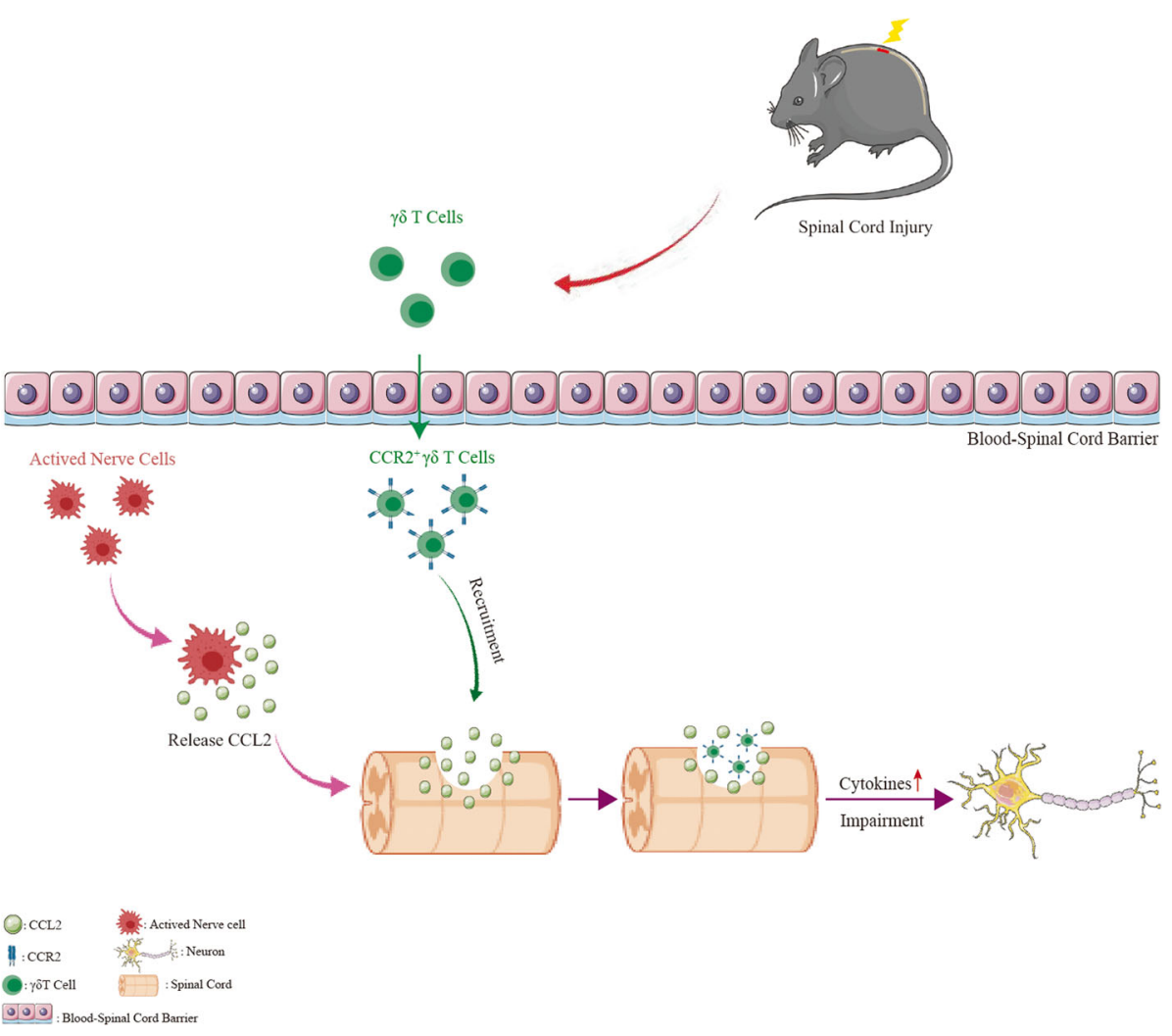

Scheme 1 Schematic illustration for the recruitment mechanism of $\gamma \delta$ T cells to the site of spinal cord injury 
leading to the aggregation of $\gamma \delta$ T cells to the inflammation site mainly through CCR2 $[8,11]$. Previous studies indicated that CCR2 induced the accumulation of $\gamma \delta \mathrm{T}$ cells in inflammatory skin caused by psoriatic arthritis and those cells mainly exhibited the CCR6 $6^{-}$-CCR2 ${ }^{+}$ phenotype $[12,13]$. Other studies have demonstrated that CCR2, rather than CCR6, is a key driver of $\gamma \delta \mathrm{T}$ cell recruitment to the central nervous system in encephalomyelitis models [14]. Collectively, we proposed the following hypothesis: $\gamma \delta \mathrm{T}$ cells may be recruited to the injury site via CCL2/CCR2 signaling after SCI (Scheme 1).

In order to test this hypothesis, we performed a comprehensive research to investigate the recruitment mechanism of $\gamma \delta \mathrm{T}$ cells to the lesion after SCI, by utilizing $\mathrm{TCR} \delta^{-1-}, \mathrm{CCL}_{2}{ }^{-1-}$, and CCR2 ${ }^{-1-}$ mice from Jackson Laboratory. Our results suggested that $\mathrm{TCR} \delta^{-1-}$ mice showed improved function recovery after SCI. $\gamma \delta$ T cell recruitment to the SCI site was significantly reduced and motor functional improvement was elevated in $\mathrm{CCL} 2^{-/-}$ and $\mathrm{CCR} 2^{-/-}$mice. Additionally, reconstitution of $\mathrm{TCR} \delta^{-/-}$mice using $\gamma \delta \mathrm{T}$ cells extracted from $\mathrm{CCR} 2^{-/-}$ mice also showed similar results to CCL2 and CCR2 deficient mice.

\section{Methods and materials}

\section{Animals}

C57bL/6 (No. 000664), TCR $\delta^{-/-}$(No. 002120), CCL2 ${ }^{-/-}$ (No. 004434), and CCR2 ${ }^{-1-}$ (No. 004999) mice were purchased from the Jackson Laboratory. All mice were females with average age of 6-8 weeks old and weight of $17-22 \mathrm{~g}$ at time of surgery; they were maintained under pathogen-free conditions in the animal facility at Jinan University. All procedures were approved by and performed in accordance with Jinan University's Institutional Laboratory Animal Care and Use Committee.

\section{Cerebrospinal fluid collection from patients}

Patients suffering acute SCI were recruited at The First Affiliated Hospital of Jinan University by spinal surgeons from June 2016 to July 2020. Patients met by the following criteria were included: (1) American Spinal Injury Association (ASIA) grade A or B SCI upon presentation; (2) the lesion segment was between $\mathrm{C} 4$ and T10 inclusive; (3) within $48 \mathrm{~h}$ after SCI and the ability to complete appropriate neurological examination. The excluded criteria included (1) concomitant head injuries; (2) concomitant serious chest trauma, pelvis, or extremities that required surgical intervention (e.g., chest tube, internal or external fixation); and (3) without ability to undergo a reliable neurological examination. Myelotomy was performed by experienced surgeons to achieve the cerebrospinal fluid (CSF) from SCI patients. In order to obtain the control samples from non-SCI patients, we enrolled individuals who had knee osteoarthritis and underwent knee replacements under spinal anesthesia. A 1.5-2.0-ml sample of CSF was collected with a spinal needle that used to punctured the dura. After that, the anesthetic agent was injected. The clinical experiment was approved by the Human Ethics Committee of Jinan University, and the CSF collection was approved by patients.

\section{Regents}

Anti-mouse CCL2 (\#2029S) was purchased from Cell Signaling Technology. Anti-mouse CCR2 (ab203128) and TCR $-\gamma / \delta$ (ab231545) were purchased from Abcam Co., LTD. The enzyme-linked immunosorbent assays (ELISA) kits were purchased from Invitrogen Co., LTD. RNAeasy $^{\text {Tm }}$ Animal RNA Isolation Kit was purchased from Beyotime Co., LTD. ReverTra Ace qPCR RT Kit and $\mathrm{SYBR}^{\circ}$ Green Realtime PCR assay kits were purchased from TOYOBO Co., LTD.

\section{Contusion model of spinal cord}

SCI model was completed by use of New York University impactor as previously described [15]. Firstly, mice were anesthetized by the peritoneal injection of $7 \%$ chloral hydrate, and then underwent a laminectomy at the T11 and T12. After stabilizing the spine, a 10-g rod was released to hit the exposed dorsal surface of the cord from a height of $6.25 \mathrm{~mm}$. Subsequently, muscles and skin were stitched in layers, and after mice underwent surgery were maintained in a suitable environment. Manual bladder emptying was completed twice daily until the recovery of reflex bladder emptying.

\section{Tissue processing}

After deep anesthetization using Chloral hydrate $(7 \mathrm{mg} /$ $\mathrm{kg}$ ), $20 \mathrm{ml}$ PBS was transcardially perfused, followed by $4 \%$ paraformaldehyde (PFA). A $5 \mathrm{~mm}$ segment of cord centered on T11 was then removed and quickly soaked in $4 \%$ PFA at $4^{\circ}$ overnight; subsequently, that segment was transferred into $15 \%$ sucrose solution until the tissues sank. This was followed by $30 \%$ sucrose solution using the same procedure.

\section{Histology and immunofluorescence}

The 15- $\mu \mathrm{m}$-thick serial frozen sections of spinal cords were stained with $0.1 \%$ cresyl violet to image surviving neurons at lesion epicenter. For immunofluorescence, frozen samples were cut into $10 \mu \mathrm{m}$ sections (Leica). Slices were permeabilized by $0.2 \%$ Triton X-100 (SigmaAldrich), then incubated with the following mousespecific primary antibodies overnight: 1:100 anti-CCR2 and 1:50 anti-TCR- $\gamma / \delta$. Subsequently, both or single staining were performed using 1:1000 fluorescent Alexa Fluor 488 or 546 secondary antibodies (Invitrogen Vector) at room temperature for $1.5 \mathrm{~h}$. After PBST $(0.2 \%$ 
Tween-20 in PBS) washing, the tissue slices were fixed with Vectashield containing DAPI and used for visualization. In order to capture images at lesion site and perform further quantification analysis, we used an inverted fluorescence microscope (Axio Observer A1; Carl Zeiss) and ImageJ software.

\section{Western blot}

Radioimmunoprecipitation lysis buffer with $2 \mathrm{mg} / \mathrm{ml}$ aprotinin and $1 \mathrm{mM}$ PMSF was used to extract lysates from fresh tissues or cells. Then these lysates were subjected to $10,000 \mathrm{~g}$ centrifugation at $4{ }^{\circ} \mathrm{C}$ for $20 \mathrm{~min}$. The concentration of extracted protein was assessed using bicinchoninic acid protein assay kit. Finally, immunoblotting was conducted according to reported previously [16].

\section{ELISA}

For mouse, CCL2 (Invitrogen Catalog 88-7391-77) and inflammatory cytokines concentrations extracted from fresh injury cord were quantified by associated ELISA kit. For human, the content of MCP-1 in cerebrospinal fluid (CSF) of SCI or non-SCI patients was measured by the same method as above (Invitrogen Catalog 88-739922). Fresh samples from each experiment were tested in triplicate in accordance with the manufacturer's instructions.

\section{Quantitative real-time polymerase chain reaction}

We used RNAeasy ${ }^{\text {mm }}$ Animal RNA Isolation Kit (Beyotime) to extract RNA from fresh spinal cord tissue. The extracted RNA was denatured at $65{ }^{\circ} \mathrm{C}$ for $5 \mathrm{~min}$ and immediately cooled, followed by synthetic of cDNA with ReverTra Ace qPCR RT Kit (TOYOBO). qRT-PCR primers for the genes listed in Additional file 1: Table S1 were purchased from Shanghai Generay Biotech Co., LTD., after which, $\mathrm{SYBR}^{\circ}$ Green Realtime PCR assay kit (TOYOBO) was used to perform qRT-PCR. Each sample was performed in triplicate. Data were normalized to the reference gene (GAPDH) and expressed as fold change.

\section{Basso Mouse Scale}

The Basso Mouse Scale (BMS) for locomotion is based on a scale ranging from 0 (no ankle movement) to 9 (complete normality) [17]. The mice were kept in an open area surrounded by plates for $4 \mathrm{~min}$. Hind limb motor ability was independently assessed by two observers and the mean locomotion score was considered the individual's BMS by both.

\section{CatWalk-assisted gait analysis}

At 6 weeks post-injury, an automatic quantitative gait analysis system (CatWalk XT; Noldus) was used to evaluate the gait of mice from each group. Each mouse required continuous walking along a $50 \mathrm{~cm}$ path on a glass plate, and was completed at least three times. The CatWalk system automatically recognized and marked each paw print, then generated a series of parameters involving paw statistics, mean speed and cadence, step sequence, and basics of support. The walking coordination was evaluated using the regularity index as described previously [18], calculated as the number of normal step sequence patterns multiplied by four and divided by the total amount of paw placements; that value is $~ 100 \%$ in normal animals. The max contact area refers to the maximal area of contact between the paw and the walking floor.

\section{Motor-evoked potential testing}

The motor-evoked potential testing (MEPs) of mice were assayed by electromyography at the 6 weeks post-injury as described before [19], with minor modifications. A stimulating electrode was placed in the rostral end of surgical exposure area and a recording electrode was placed in their bicep flexor muscles. Subsequently, a single square wave stimulus of $0.5 \mathrm{~mA}$ was used, with a 0.5 ms duration, a delay of $2 \mathrm{~ms}$, and $1 \mathrm{~Hz}$. Measuring the amplitude from the initiation point of the first reaction wave to its highest point, the nerve conduction function in the hind limb was indicated by the peak-to-peak amplitude $(P-P$ value $)$.

\section{$\gamma \delta \mathrm{T}$ cell proliferation and transplantation}

In order to determine the proliferation of splenic $\gamma \delta \mathrm{T}$ cells from WT or $\mathrm{CCR}^{-/-}$mice $(n=10 \mathrm{mice} / \mathrm{per}$ group) in vitro, splenic $\gamma \delta$ T cells were activated by purified anti-mouse TCR- $\delta(10 \mu \mathrm{g} / \mathrm{ml})$ and soluble antiCD28 antibody $(1 \mu \mathrm{g} / \mathrm{ml})$ and expanded for 6 days in the presence of IL-2 $(2 \mathrm{ng} / \mathrm{ml})$ as previously described [2022]. Then, expanded cells were magnetic-activated cell sorting (MACS) sorted by biotin-conjugated anti-TCR- $\delta$ antibody and used for subsequent experiments (99\% purity). For transplantation of cells, the mice were immobilized by a tail vein injection fixator. Then, splenic $\gamma \delta \mathrm{T}$ cells from WT or CCR2 ${ }^{-/-}$mice were injected intravenously into $\mathrm{TCR}^{-1-}$ mice $\left(2 \times 10^{6}\right.$ cells/per mouse). One day after the transplantation, all mice were subjected to SCI, and ethology evaluation followed.

\section{Statistical analysis}

The Prism 7 software (Graphpad) was used to process and analyze all data. Values were presented as mean \pm standard difference (SD) or standard error of mean (SEM). A two-way ANOVA was performed to test the significance in BMS score between groups over time. Remaining data were analyzed using Student's $t$ test or one-way ANOVA with Tukey's multiple comparison test. Values were regarded as significant at $P<0.05$. 


\section{Results}

$\gamma \delta \mathrm{T}$ cells play a detrimental role in $\mathrm{SCl}$

We performed a moderate contusion at the T11 levels of $\mathrm{TCR} \delta^{-/-}$and age-matched WT mice; the spontaneous improvement of hind limb motor ability was evaluated through the BMS. Our results suggested that both
$\mathrm{TCR} \delta^{-/-}$and WT mice groups presented complete hind limb paralysis with a BMS score of 0 at 1 day postinjury. Beginning from 3 days post-injury, $\mathrm{TCR} \delta^{-/-}$mice recovered gradually, and their BMS scores increased progressively (Fig. 1a). By comparison, motor improvement in WT mice group was obviously slower, and their

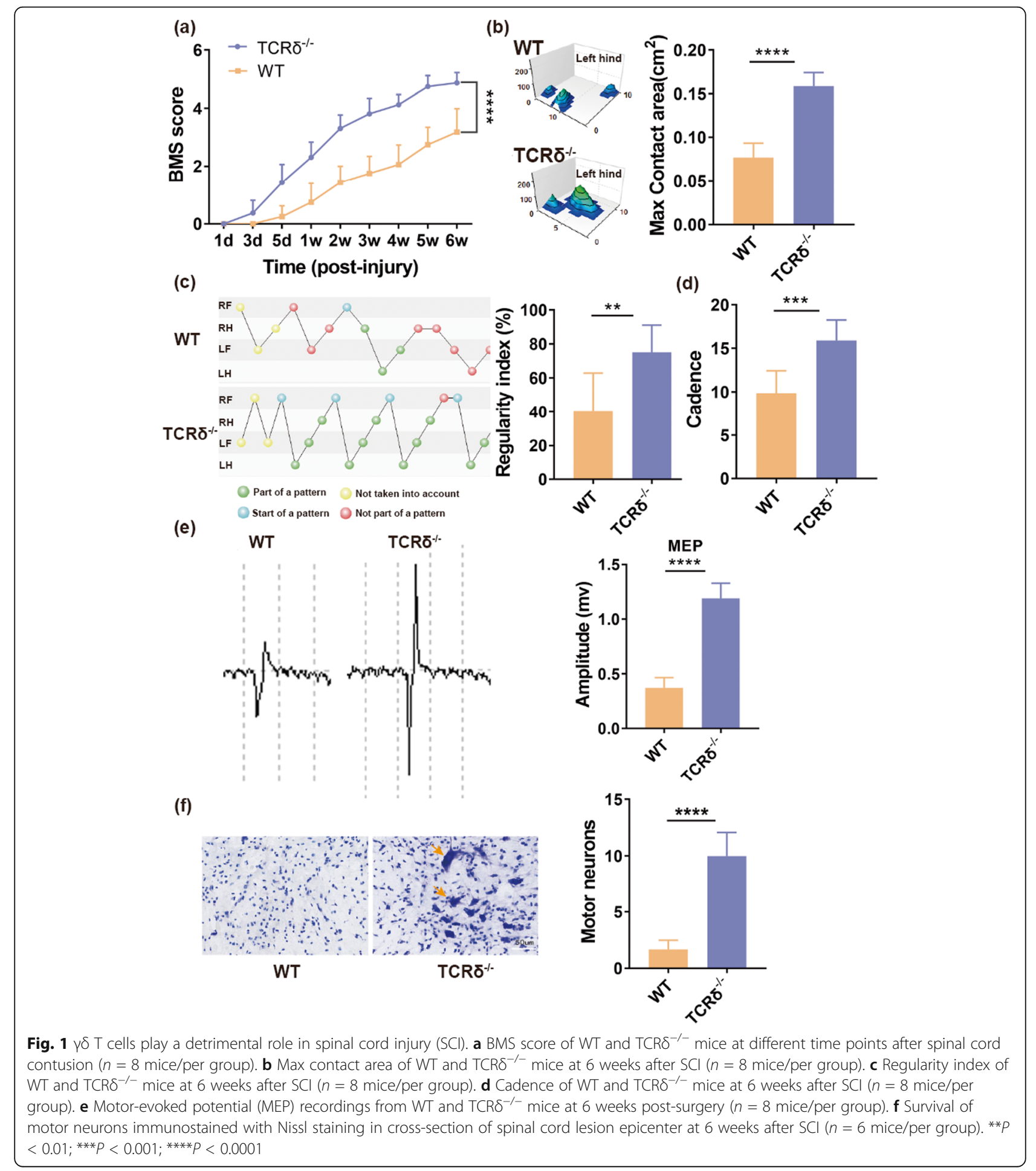


mean BMS score was significantly lower than those of $\mathrm{TCR}^{-/-}$mice group at 6 weeks post-injury $(3.19 \pm 0.8$ vs. $4.89 \pm 0.35, P<0.0001$, Fig. $1 \mathrm{a}, n=8 \mathrm{mice} / \mathrm{per}$ group). In terms of max contact area, regularity index, and cadence, compared with WT mice group, TCR $\delta^{-1-}$ mice group had a larger mean max contact area $(0.16 \pm$ 0.02 vs. $0.08 \pm 0.02 \mathrm{~cm}^{2}, P<0.0001$, Fig. $1 \mathrm{~b}, n=8$ mice/ per group), a higher mean regularity index (75.23 \pm $15.99 \%$ vs. $40.29 \pm 22.61 \%, P<0.01$, Fig. 1 c, $n=8$ mice $/$ per group), and greater mean cadence $(15.9 \pm 2.36$ vs. $9.89 \pm 2.55, P<0.001$, Fig. $1 \mathrm{~d}, n=8 \mathrm{mice} / \mathrm{per}$ group) at 6 weeks after injury. To further confirm this, electromyography of biceps flexor cruris was recorded through stimulating the dura mater at the T6 level at 6 weeks post-injury. Our results demonstrated that a higher mean amplitude of motor-evoked potentials (MEPs) was found in $\mathrm{TCR} \delta^{-/-}$mice group than in WT mice group $(1.19 \pm 0.14$ vs. $0.37 \pm 0.09 \mathrm{mV}, P<0.0001$, Fig. $1 \mathrm{e}, n=$ $8 \mathrm{mice} /$ per group), indicating a better improvement of motor function of injury to hind limbs in $\mathrm{TCR} \delta^{-/-}$mice group compared to WT mice group. In addition, to evaluate whether motor neurons of $\mathrm{TCR} \delta^{-1-}$ mice group were better protected than those of WT mice group, we performed a Nissl staining to measure the number of survival motor neurons of lesion epicenter in cross section at 6 weeks post-injury. Our results meant that more survival motor neurons were found in $\mathrm{TCR} \delta^{-1-}$ mice compared with WT mice $(10 \pm 2.1$ vs. $1.67 \pm 0.82, P<$ 0.0001 , Fig. 1f, $n=6$ mice/per group). All above results suggested that assemblage of $\gamma \delta \mathrm{T}$ cells resulted in the aggravation of lesions and hampered function recovery after SCI.

\section{Increased secretion of CCL2 after $\mathrm{SCl}$}

To investigate whether amounts of CCL2 were secreted after SCI, we evaluated the level of CCL2 at different time points in the CSF after SCI or laminectomy (sham) using ELISA kit. Our results showed that the expression level of CCL2 increased significantly at $12 \mathrm{~h}$ to 1 day after SCI compared with sham group (12 h: $871.2 \pm$ 99.58 vs. $58.33 \pm 9.82 \mathrm{pg} / \mathrm{ml}, P<0.05 ; 1$ day: $967.5 \pm$ 611.6 vs. $58.33 \pm 9.82 \mathrm{pg} / \mathrm{ml}, P<0.01$, Fig. $2 \mathrm{a}, n=3$

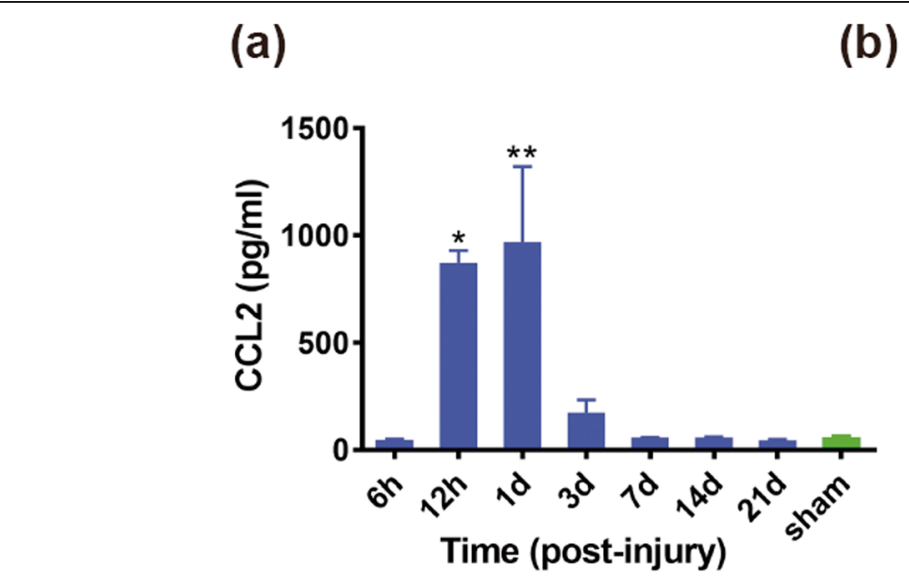

(b)

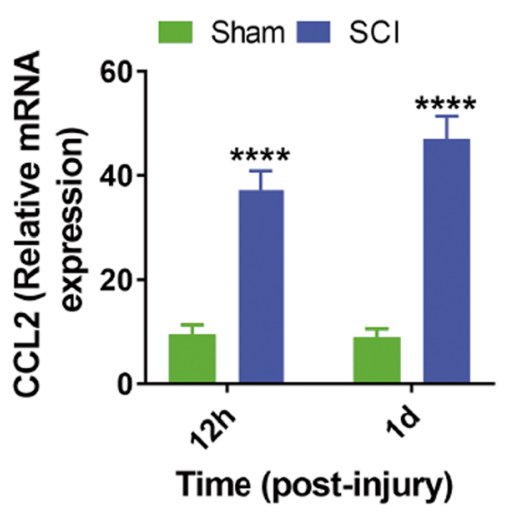

(c)
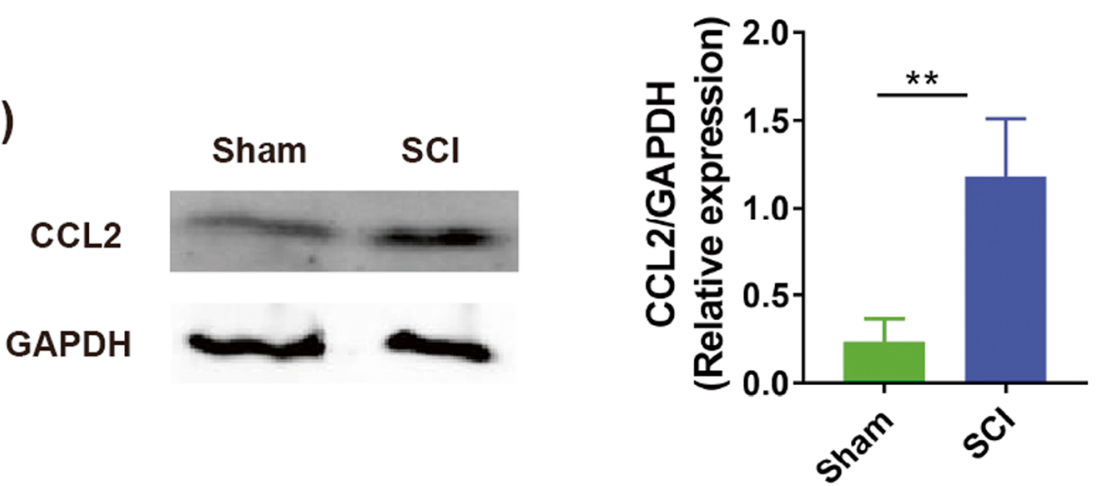

Fig. 2 Increased secretion of CCL2 after spinal cord injury (SCI). a The levels of CCL2 was significantly increased at 12 h and 1 day after SCl compared with that of sham group ( $n=3$ mice/per group). b QRT-PCR quantitative analysis of CCL2 expression at 12 h and 1 day after SCI and sham ( $n=8$ mice/per group). c The protein level of CCL2 was obviously higher in SCl group than that of sham group at 1 day after surgery $(n=$ 3 mice/per group). ${ }^{*} P<0.05 ;{ }^{* *} P<0.01 ;{ }^{* * *} P<0.0001$ 
mice/per group). Additionally, the gene expression of CCL2 in the associated cord at $12 \mathrm{~h}$ and 1 day after injury or laminectomy was evaluated through quantitative real-time polymerase chain reaction (QRT-PCR) testing. Our results demonstrated that a higher gene expression of CCL2 was found in SCI group than in sham group (12 h: $37.2 \pm 3.65$ vs. $9.45 \pm 1.85 \mathrm{pg} / \mathrm{ml}, P<0.0001 ; 1$ day: $47.03 \pm 4.38$ vs. $8.95 \pm 1.67 \mathrm{pg} / \mathrm{ml}, P<0.0001$, Fig. $2 \mathrm{~b}, n=8 \mathrm{mice} /$ per group). Meanwhile, we also performed an immunoblotting to evaluate the level of CCL2 protein in spinal cord after SCI or laminectomy. Our results demonstrated that SCI group had a greater CCL2 protein level compared with sham group $(1.18 \pm 0.33$ vs. $0.23 \pm 0.13, P<0.01$, Fig. 2 c, $n=6$ mice/per group). To further identify this, we also assessed the level of MCP-1 in the CSF of SCI patients (Fig. 3a, $n=6$ ) at 1 day after injury or control group $(n=20)$. We found that compared to control group, SCI patients group had significantly higher levels of MCP-1 in CSF $(639.35 \pm 46.48$ vs. $119.05 \pm 20.31 \mathrm{pg} / \mathrm{ml}, P<0.0001$, Fig. 3b). These outcomes indicated that amounts of CCL2/MCP-1 were released after SCI.

\section{High expression of CCR2 on the surface of $\gamma \delta \mathrm{T}$ cells}

To confirm whether CCR2, a special receptor of CCL2, was highly activated on the surface of $\gamma \delta$ T cells after SCI, we performed an immunofluorescence for $\gamma \delta \mathrm{T}$ cells and CCR2 in lesion epicenter cross-section of cord after SCI or laminectomy. We found that amounts of $\gamma \delta \mathrm{T}$ cells, highly presenting CCR2 ${ }^{+}$, were recruited in SCI site, but laminectomy group did not exhibit this $(67.5 \pm 6.83 \%$ vs. $2.18 \pm 0.82 \%, P<0.0001$, Fig. 4a, b, $n=6$ mice/per group). Furthermore, the results of QRT-PCR showed that the gene expression of CCR2 in SCI group was much higher than that in sham group $(2.03 \pm 0.52$ vs. $0.72 \pm 0.23, P<$ 0.01 , Fig. $4 \mathrm{c}, n=8$ mice/per group). To further confirm this, we conducted an immunoblotting to measure the expression level of CCR2 protein in spinal cord after SCI or laminectomy. Our results showed that a higher level of CCR2 was found in SCI group than in sham group $(0.67 \pm$ 0.11 vs. $0.25 \pm 0.08, P<0.01$, Fig. $4 \mathrm{~d}, n=6$ mice/per group). These outcomes suggested that CCR2 was highly activated on the surface of $\gamma \delta$ T cells after SCI.

\section{CCL2 depletion contributes to decreased recruitment of $\gamma \delta \mathrm{T}$ cells at $\mathrm{SCl}$ site}

To define whether CCL2 plays a vital role during the migration of $\gamma \delta \mathrm{T}$ cells to lesions after SCI, we performed an immunostaining to evaluate the aggregation of $\gamma \delta \mathrm{T}$ cells at the site of lesions using anti-TCR- $\gamma / \delta$ in both $\mathrm{CCL}^{-/-}$and WT mice groups. Our results suggested that the CCL2 $2^{-/-}$mice group had significantly less $\gamma \delta \mathrm{T}$ cells at the epicenter site of injury compared to WT mice group ( $18 \pm 4 \%$ vs. $82.83 \pm 6.18 \%, P<0.0001$, Fig. 5f, $n=6$ mice/per group). Meanwhile, we also assessed the BMS score, regularity index, cadence, and MEPs. We found that CCL2 $2^{-/-}$mice recovered progressively, and had a higher mean BMS score at 6 wk post-injury compared with WT mice $(4.85 \pm 0.18$ vs. $2.72 \pm 0.23, P<$ 0.0001 , Fig. $5 \mathrm{a}, n=8 \mathrm{mice} /$ per group). This significant difference was also presented in an enlarged max contact area $\left(0.17 \pm 0.03\right.$ vs. $0.06 \pm 0.02 \mathrm{~cm}^{2}, P<0.001$, Fig. $\left.5 \mathrm{~b}\right)$ increased regularity index $(75.17 \pm 4.88 \%$ vs. $41 \pm 2.61 \%$, $P<0.0001$, Fig. 5 c), enhanced cadence $(15.5 \pm 1.87$ vs. $10 \pm 1.41, P<0.01$, Fig. $5 \mathrm{~d})$ and boosted MEPs $(1.25 \pm$ 0.19 vs. $0.28 \pm 0.15 \mathrm{mv}, P<0.0001$, Fig. 5 e) in CCL2 ${ }^{-/-}$ mice at 6 weeks post-injury, compared to WT mice $(n=$ 8 mice/per group). In addition, a Nissl staining was performed to compare the number of survival motor neurons of lesion epicenter in cross-section between $\mathrm{CCL}^{-1-}$ and WT mice groups at 6 weeks after injury. Our results demonstrated that more motor neurons were found in CCL2 ${ }^{-/-}$mice than in WT mice $(12.17 \pm$ 2.32 vs. $2.83 \pm 1.94, P<0.01$, Fig. 5 g, $n=6$ mice $/$ per (a)

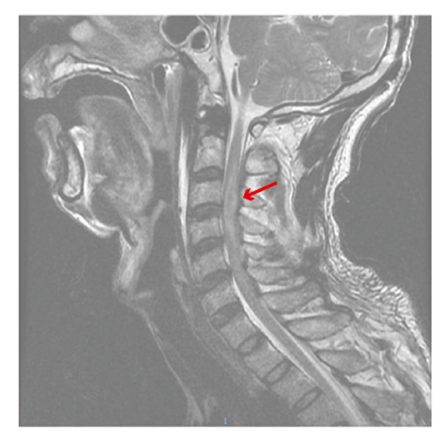

(b)

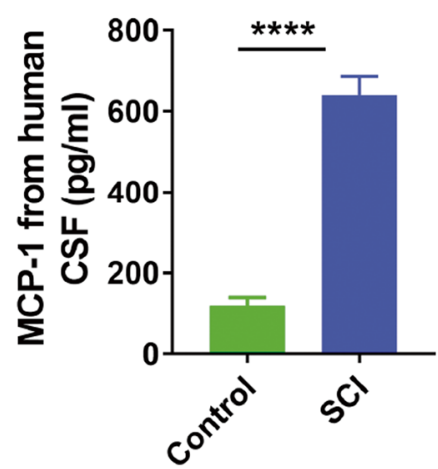

Fig. 3 Increased secretion of MCP-1 after spinal cord injury (SCI) a magnetic resonance imaging of SCI patient. b The comparison of MCP-1 levels of cerebrospinal fluid (CSF) between SCI $(n=6)$ and control group $(n=20)$. ${ }^{*} P<0.05 ;{ }^{*} P<0.01$; ${ }^{* * *} P<0.0001$ 


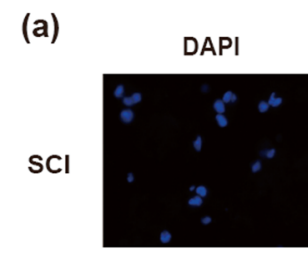

DAPI

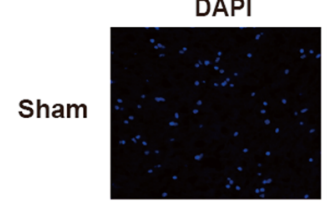

(b)

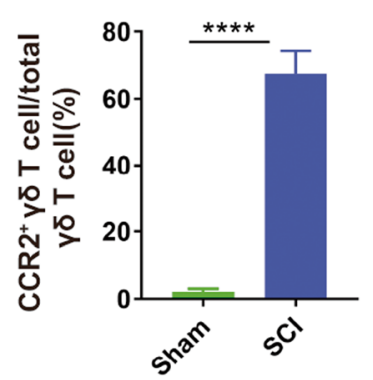

(d)

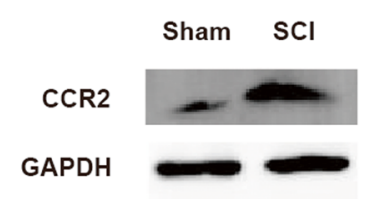

TCRY $\delta$

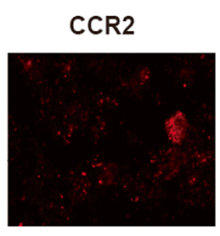

CCR2
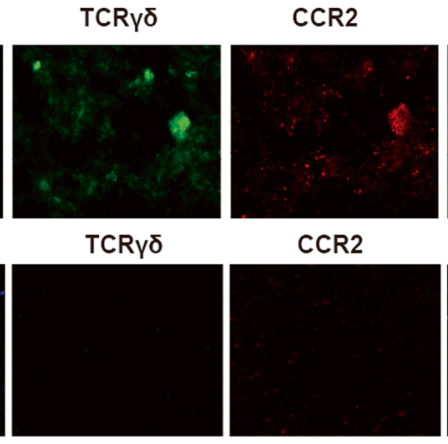

(c)
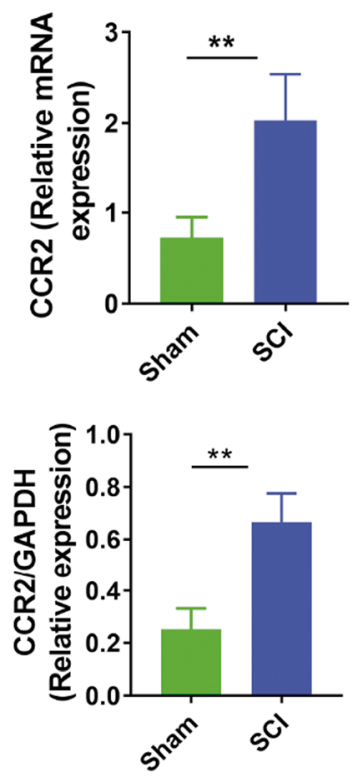

Fig. 4 High expression of CCR2 on surface of $\gamma \delta$ T cells after spinal cord injury (SCI). a Spinal sections from mice after $1 \mathrm{~d}$ post-SCl and sham were immunostained with anti-TCRү $\delta$ (green, a maker for $\gamma \delta$ T cell) and anti-CCR2 (red) ( $n=6$ mice/per group). $\mathbf{b}$ Statistic histogram of the percent of $\mathrm{CCR}^{+} \gamma \delta \mathrm{T}$ cell $\left(\mathrm{CCR} 2^{+} /\right.$total $\gamma \delta \mathrm{T}$ cell, $n=6$ mice/per group). $\mathbf{c}$ The gene expression of CCR2 at $1 \mathrm{~d}$ post-SCl and sham ( $n=8 \mathrm{mic} /$ per group). $\mathbf{d}$ Comparison of protein level of CCR2 between SCl and sham groups (1d post-surgery, $n=6$ mice/per group). ${ }^{*} P<0.01 ;{ }^{* * *} P<0.0001$

group). Those outcomes indicated that depletion of CCL 2 contributed to decreased aggregation of $\gamma \delta$ T cells at the site of lesions and further promoted function recovery.

\section{CCR2 depletion contributes to decreased recruitment of $\delta \mathrm{T}$ cells at $\mathrm{SCl}$ site}

To investigate whether CCR2 mediated the recruitment of $\gamma \delta \mathrm{T}$ cells to the lesions after SCI, we drew a comparison on the aggregation number of $\gamma \delta \mathrm{T}$ cells at SCI site between CCR2 $2^{-1-}$ and WT mice groups. Our results demonstrated that less numbers of $\gamma \delta$ T cells were found at lesion epicenter site of CCR2 ${ }^{-1-}$ mice group, compared with WT mice group $(9.67 \pm 2.16 \%$ vs. $67 \pm 5.22 \%, P<0.0001$, Fig. 6f, $n=6$ mice/per group). In addition, the BMS score, max contact area, regularity index, cadence, and MEPs also were assessed to compare the motor function recovery between $\mathrm{CCR}^{-1-}$ and WT mice groups. We found that compared to WT mice, CCR2 $2^{-1-}$ mice had earlier and faster BMS score recovery, and their mean BMS score was higher at 6 weeks after SCI $(5 \pm 0.54$ vs. $3.44 \pm 0.78, P<0.0001$, Fig. 6a, $n=8$ mice/per group). Similar differences appeared in max contact area $\left(0.16 \pm 0.05\right.$ vs. $0.06 \pm 0.03 \mathrm{~cm}^{2}, P<0.01$, Fig. 6b), regularity index $(70.41 \pm 14.98 \%$ vs. $46.96 \pm$ $20.47 \%, P<0.05$, Fig. $6 \mathrm{c})$, cadence $(15 \pm 2.82$ vs. $11.51 \pm$ 2.34, $P<0.05$, Fig. $6 \mathrm{~d})$, and MEPs $(1.18 \pm 0.17$ vs. $0.36 \pm 0.1$ mv, $P<0.0001$, Fig. 6e) between CCR2 $2^{-1-}$ and WT mice groups at 6 weeks post-injury ( $n=8$ mice/per group). To further confirm this, the amount of survival motor neurons at lesion epicenter was measured by a Nissl staining at 6 weeks after SCI. Our results showed that $\mathrm{CCR}^{-/-}$mice had more motor neurons compared to WT mice (15.33 \pm 3.14 vs. $3.83 \pm 1.6, P<0.0001$, Fig. 6 g, $n=6$ mice/per group). According to those results, we knew that CCR2 mediated the recruitment of $\gamma \delta$ T cells to lesions, and its depletion enhanced motor recovery. 

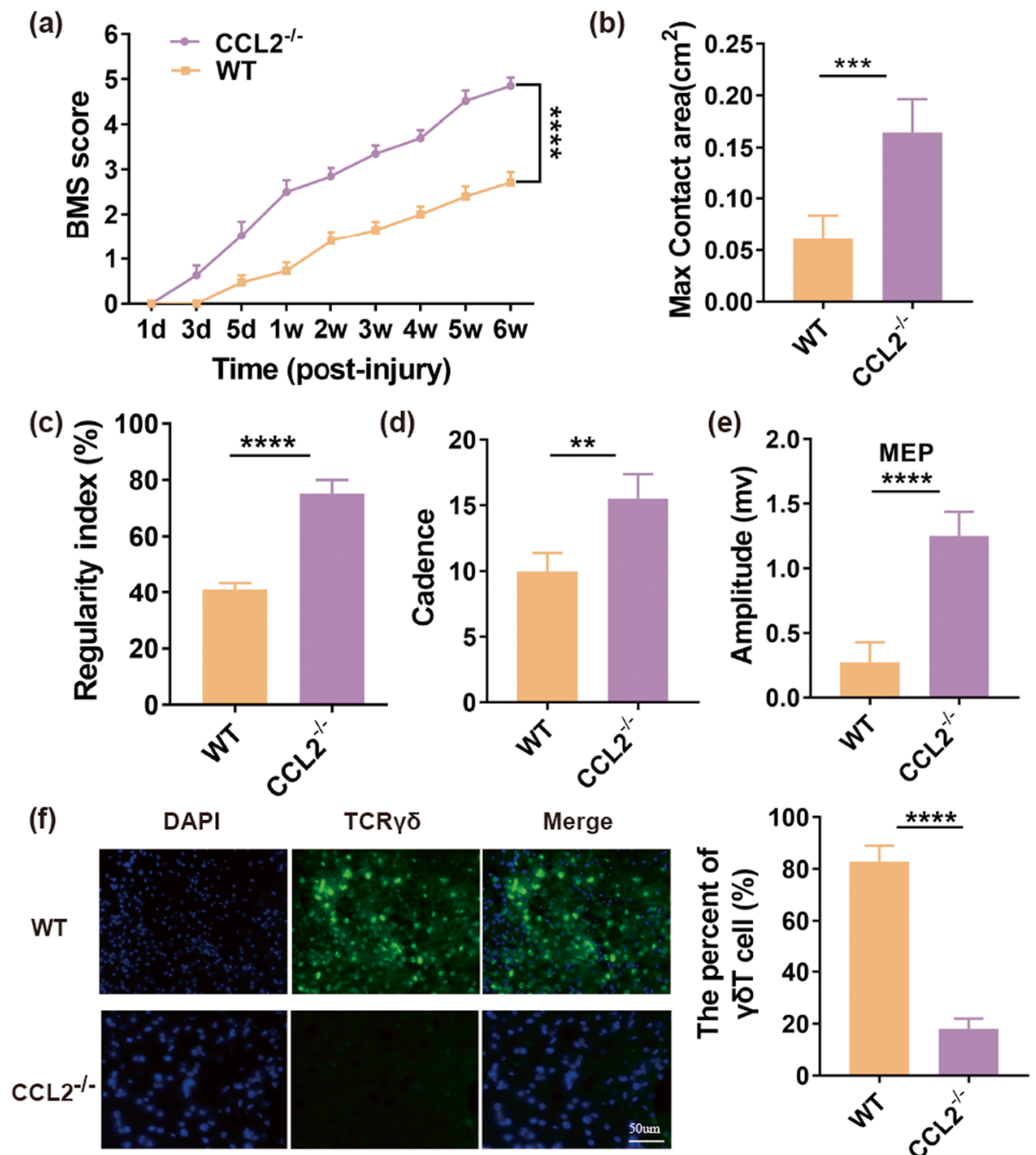

(g)
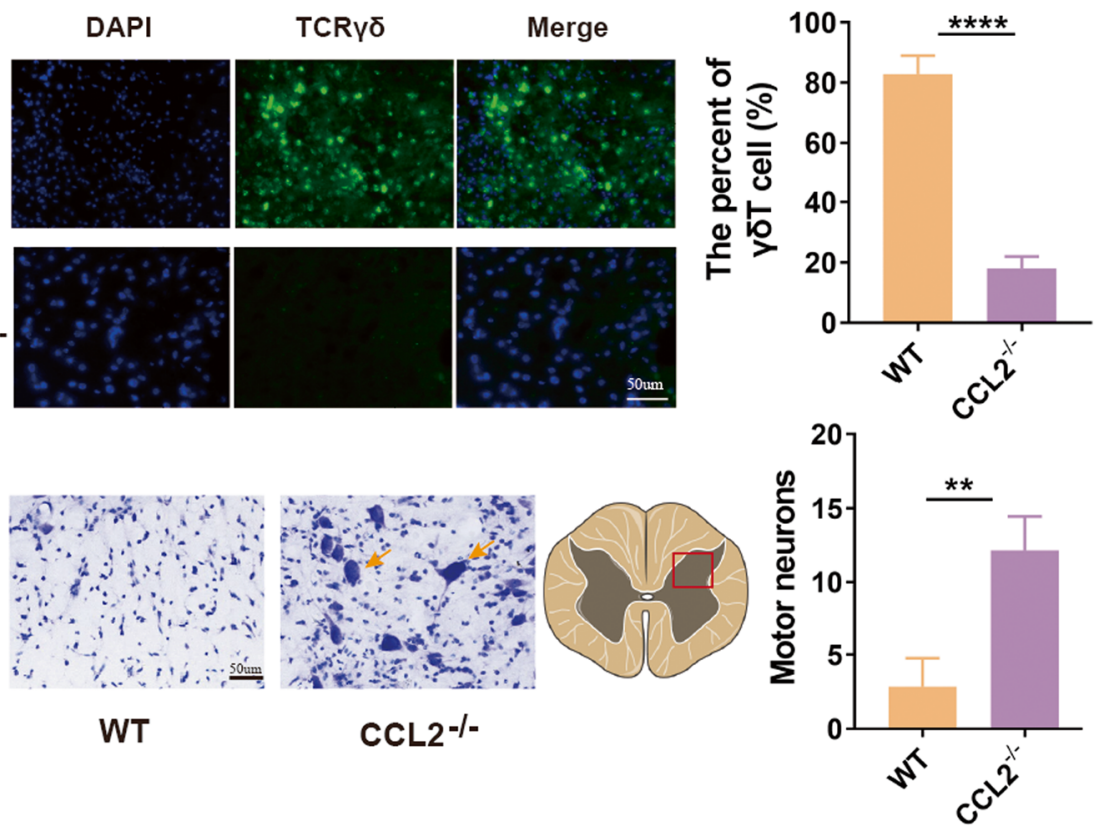

Fig. $5 \mathrm{CCL} 2$ plays an important role during recruitment of $\gamma \delta \mathrm{T}$ cells to lesions. a BMS score of WT and $\mathrm{CCL}^{-/-}$mice at different time points after spinal cord injury (SCI) ( $n=8$ mice/per group). b Max contact area of WT and CCL2 ${ }^{-1}$ mice at 6 weeks after SCl ( $n=8$ mice/per group). $\mathbf{c}$ Regularity index of WT and $\mathrm{CCL}^{-1-}$ mice at 6 weeks after SCl ( $n=8$ mice/per group). $\mathbf{d}$ Cadence of WT and CCL2 ${ }^{-1-}$ mice at 6 weeks after SCl $(n=8 \mathrm{mice} /$ per group). e Motor-evoked potential (MEP) recordings from WT and CCL2 ${ }^{-1-}$ mice at 6 weeks post-surgery ( $n=8$ mice/per group). f Spinal sections from $\mathrm{WT}$ and $\mathrm{CCL}_{2}^{-1-}$ mice after 1 day post-SCI were immunostained with anti-TCR $\gamma \delta$ (green, a maker for $\gamma \delta \mathrm{T}$ cell) and the corresponding static histogram of percent of $\gamma \delta$ T cell ( $\gamma \delta$ T cells/total cells) ( $n=6$ mice/per group). $\mathbf{g}$ Survival of motor neurons immunostained with Nissl staining in cross-section of spinal cord lesion epicenter at 6 weeks after SCl ( $n=6$ mice/per group). ${ }^{* *} P<0.01 ;{ }^{* *} P<0.001$; ${ }^{* * *} P<0.0001$

$\delta$ T cells from $\mathrm{CCR2}^{-/-}$or WT mice were transferred into $\mathrm{TCR}^{-/-}$mice

To further confirm that CCR2 played a key part in the recruitment of $\gamma \delta \mathrm{T}$ cells to lesions after SCI, $\gamma \delta \mathrm{T}$ cells from $\mathrm{CCR}^{-/-}$or WT mice were transferred into $\mathrm{TCR} \delta^{-/-}$mice 1 day before SCI. Then BMS score, max contact area, regularity index, cadence, and MEPs were evaluated. Our results suggested that $\mathrm{TCR} \delta^{-1-}$ mice 

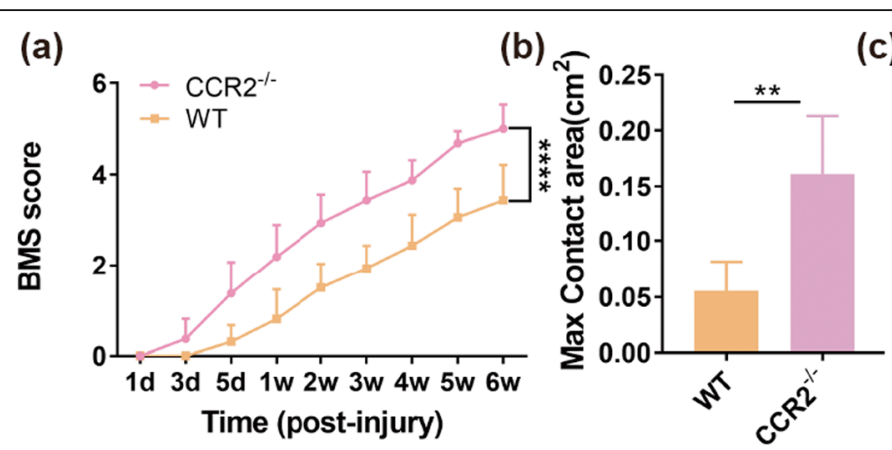

(c)
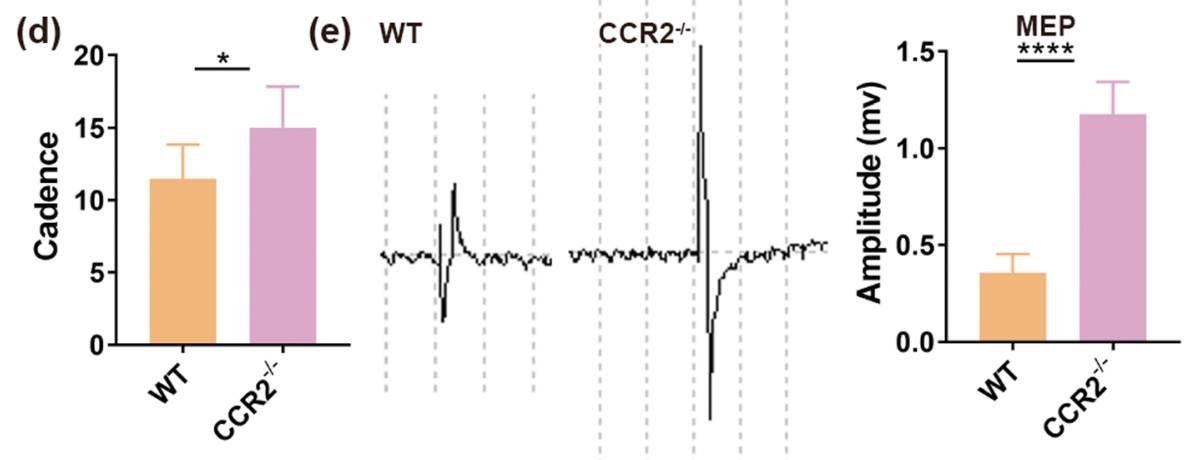

(f)
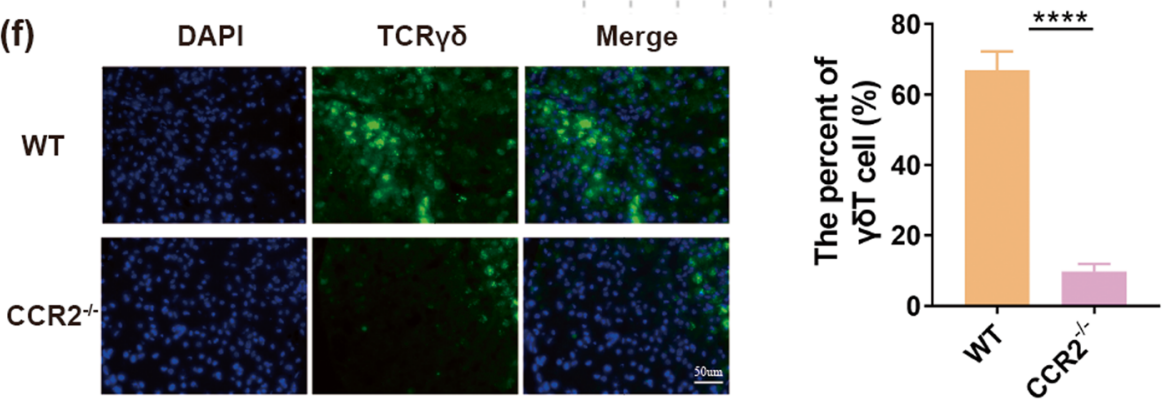

(g)
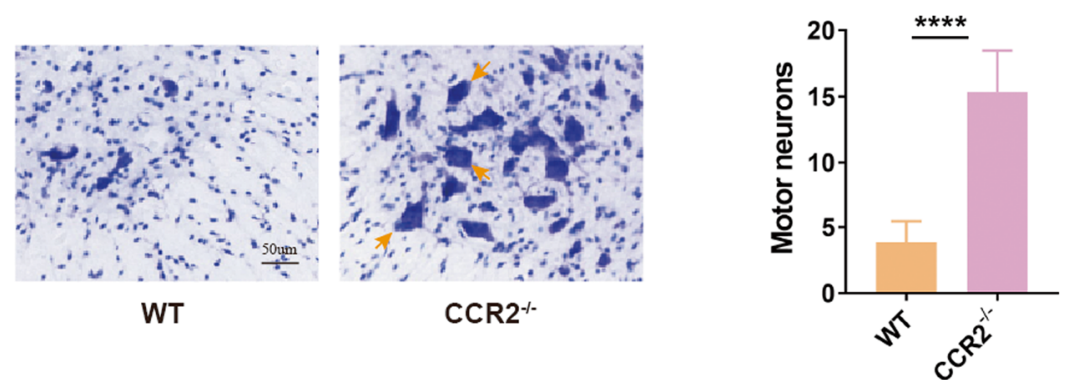

Fig. 6 CCR2 plays a vital role during recruitment of $\gamma \delta$ T cell to lesions. a BMS score of WT and CCR2 ${ }^{-1-}$ mice at different time points after spinal cord injury (SCI) ( $n=8$ mice/per group). b Max contact area of WT and $\mathrm{CCR}^{-1-}$ mice at 6 weeks after SCI ( $n=8$ mice/per group). c Regularity index of WT and $\mathrm{CCR}_{2}^{-1-}$ mice at 6 weeks after SCl ( $n=8$ mice/per group). $\mathbf{d}$ Cadence of WT and CCR2 ${ }^{-1-}$ mice at 6 weeks after SCl $(n=8$ mice/per group). e Motor-evoked potential (MEP) recordings from WT and CCR2 ${ }^{-1-}$ mice at 6 weeks post-surgery $(n=8$ mice/per group). $\mathbf{f}$ Spinal sections from WT and $\mathrm{CCR}^{-1-}$ mice after 1 day post-SCI were immunostained with anti-TCRү $\delta$ (green, a maker for $\gamma \delta \mathrm{T}$ cell) and the corresponding static histogram of percent of $\gamma \delta$ T cell ( $\gamma \delta$ T cell/total cell) $(n=6$ mice/per group). g Survival of motor neurons immunostained with Nissl staining in cross-section of injury cord epicenter at 6 weeks after $\mathrm{SCl}\left(n=6\right.$ mice/per group). ${ }^{*} P<0.05 ;{ }^{* *} P<0.01 ;{ }^{* * *} P<0.0001$

transferred with $\gamma \delta \mathrm{T}$ cells from CCR2 ${ }^{-1-}$ mice exhibited better motor function improvement than those reconstituted with $\gamma \delta \mathrm{T}$ cells from WT mice $(n=8$ mice/per group), as shown in BMS score (4.63 \pm 0.95 vs. $3.5 \pm 0.6$, $P<0.01$, Fig. $7 \mathrm{a})$, max contact area $(0.18 \pm 0.04$ vs. 0.06 $\pm 0.04 \mathrm{~cm}^{2}, P<0.001$, Fig. 7b), regularity index $(73.45 \pm$ $15.57 \%$ vs. $51.94 \pm 23.51 \%, P<0.05$, Fig. $7 \mathrm{c})$, cadence $(15.18 \pm 2.54$ vs. $11.11 \pm 2.77, P<0.01$, Fig. $7 d)$, and MEPs $(1.12 \pm 0.17$ vs. $0.38 \pm 0.09 \mathrm{mv}, P<0.0001$, Fig. 7e). Moreover, we performed anti-TCR- $\gamma / \delta$ 
immunostaining for the cross-section of injury site. We found that $\mathrm{TCR} \delta^{-1-}$ mice reconstituted with $\gamma \delta \mathrm{T}$ cells from $\mathrm{CCR} 2^{-/-}$mice presented significantly less aggregation of $\gamma \delta \mathrm{T}$ cells at lesion epicenter site compared to those transferred with WT $\gamma \delta$ T cells $(80 \pm 7.18 \%$ vs. $5.67 \pm 1.75 \%, P<0.0001$, Fig. 7 f, $n=6$ mice/per group). To further identify this, a Nissl staining was performed to assess the number of survival motor neurons of lesion epicenter in cross section of spinal cord at 6 weeks postinjury. Our results demonstrated that more motor neurons were found in $\mathrm{TCR} \delta^{-/-}$mice reconstituted with $\gamma \delta$ $\mathrm{T}$ cells from $\mathrm{CCR} 2^{-/-}$mice than in those transferred with WT $\gamma \delta \mathrm{T}$ cells $(12.83 \pm 2.32$ vs. $2.67 \pm 1.86, P<$ 0.0001 , Fig. $7 \mathrm{~g}, n=6$ mice/per group). Those results indicated again that CCR2 was involved in the recruitment of $\gamma \delta \mathrm{T}$ cells to spinal cord lesions.

Additionally, to evaluate the expression of proinflammation cytokines, we conducted inflammatory protein analysis on spinal samples of $\mathrm{TCR} \delta^{-/-}$mice reconstituted with CCR2 ${ }^{-1-} \gamma \delta \mathrm{T}$ cells or WT $\gamma \delta \mathrm{T}$ cells at 1 day after SCI (Fig. $8 \mathrm{a}, n=8$ mice/per group). Meanwhile, the secreted level of inflammatory makers such as TNF- $\alpha$, IFN- $\gamma$, IL- 6 , IL- $1 \beta$, IL- $\alpha$, and IL-10 were also measured at $1 \mathrm{~d}$ after SCI. We found that proinflammatory-associated cytokines including TNF- $\alpha$, IFN- $\gamma$, IL-17, IL-6, IL-1 $\beta$, and IL- $\alpha$ were downregulated and anti-inflammatory IL-10 was upregulated in $\mathrm{TCR} \delta^{-/-}$mice reconstituted with $\mathrm{CCR} 2^{-/-} \gamma \delta \mathrm{T}$ cells after SCI compared with those mice transferred with WT $\gamma \delta$ T cells (Fig. 8b, $n=8$ mice/per group). Above results suggested that CCR2 depletion reduced the recruitment of $\gamma \delta$ T cells to SCI site, and further decreased the production of pro-inflammatory cytokines.

\section{Discussion}

Neurological damage due to SCI is a serious central nervous system disease that is exacerbated by the infiltration of immune cells and the inflammatory response around the injury site [23]. Therefore, investigating the pathological mechanism of SCI is urgently needed for the development of a more effective treatment. In the current study, our results showed that $\gamma \delta \mathrm{T}$ cells, especially CCR2 ${ }^{+} \gamma \delta \mathrm{T}$ cells, were recruited at the injury site after SCI, which hampered motor functional improvement. Amounts of CCL2 were secreted $12 \mathrm{~h}$ to 1 day after SCI. Inactivation of CCL2 or blocking of CCR2 lead to the decreased recruitment of $\gamma \delta \mathrm{T}$ cells at SCI site and neurological function improvement compared to WT mice, further confirming a vital role of CCL2-CCR2 signaling during recruitment of $\gamma \delta \mathrm{T}$ cells to SCI site. The results of $\gamma \delta \mathrm{T}$ cells from CCR2 $2^{-/-}$or WT mice transferred to $\mathrm{TCR} \delta^{-1-}$ mice further supported our assumption. Collectively, our results demonstrated a pathological mechanism of SCI, defined the importance of CCL2-CCR2 signaling in the recruitment of $\gamma \delta$ T cells to SCI site, and provided a novel potential therapeutic target.

$\gamma \delta \mathrm{T}$ cells are a subset of $\mathrm{T}$ lymphocytes that are unevenly distributed over the tissues of the body. Moreover, $\gamma \delta \mathrm{T}$ cells perform different functions when faced with different diseases. For instance, $\gamma \delta \mathrm{T}$ cells orchestrated the progress of immune responses through producing large amount of cytokines and those cells were highly lethal to infected cells during infectious diseases [24]. However, $\gamma \delta \mathrm{T}$ cells secreted a great deal of proinflammation cytokines that induced the deterioration of lesions in an experimental autoimmune encephalomyelitis (EAE) model [25]. In addition, $\gamma \delta \mathrm{T}$ cells also exerted different functions as shown in various tumor models $[26,27]$. In the present study, our results showed that depletion of $\gamma \delta \mathrm{T}$ cells contributed to the improvement of neurological functions after SCI. Furthermore, we also found that $\gamma \delta \mathrm{T}$ cells, especially CCR $2^{+} \gamma \delta \mathrm{T}$ cells, were recruited at SCI site, and the reconstitution of $\mathrm{TCR} \delta^{-/-}$ mice with $\gamma \delta \mathrm{T}$ cells from CCR2 ${ }^{-1-}$ mice rather than WT mice improved the recovery of hind motor function. Those were consistent with the view that CCR2 may play an important role during the recruitment of $\gamma \delta \mathrm{T}$ cells to lesions after SCI.

CCL2 not only exhibits a good chemotaxis effect on immune cells but also regulates the activation and recruitment of macrophages and lymphocytes in many CNS diseases [28]. Previous evidence suggested that the expression level of CCL2 was elevated, and mainly secreted by activated microglia and astrocytes in neurological inflammatory responses [29, 30]. A similar result found in our study showed that the expression level of CCL2 increased significantly at $12 \mathrm{~h}$ to 1 day after SCI. Additionally, considerable evidence demonstrated that knock-out of CCL2 resulted in the decreased aggregation of M1 macrophages at the lesions in EAE mice models, and further slowed down the progression of neurological impairment and improved prognosis of the disease [31]. In this study, our results revealed that inactivation of CCL2 led to the reduced recruitment of $\gamma \delta$ $\mathrm{T}$ cells to the site of $\mathrm{SCI}$, and further enhanced neurological function recovery. This result indicated that CCL2 was an indispensable factor for the recruitment of immune cells such as $\gamma \delta \mathrm{T}$ cells to injury site.

CCL2 preferentially binds to the CCR2 found in a variety of tissues such as thymus, lungs, and liver [10]. Mounting data demonstrated that binding of CCL2 to the associated CCR2 contributed to the recruitment and invasion of immune cells such as macrophages and $\mathrm{T}$ lymphocyte to the lesions [32-34]. In this study, our results suggested that high levels of CCL2 and CCR2 were found in SCI, per mouse models. Meanwhile, to confirm the importance of CCL2/CCR2 axis to inflammation- 


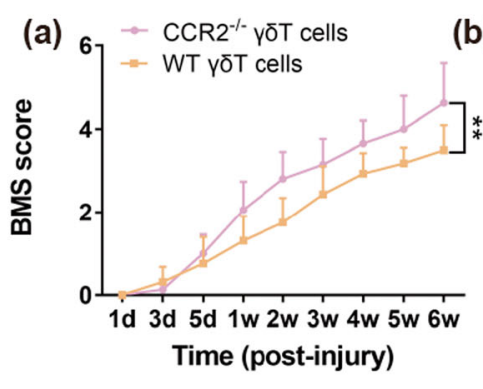

(d)

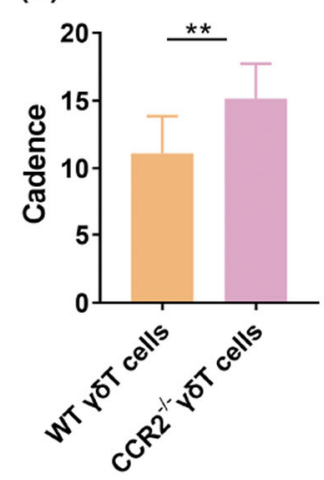

(e)

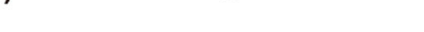

(c)

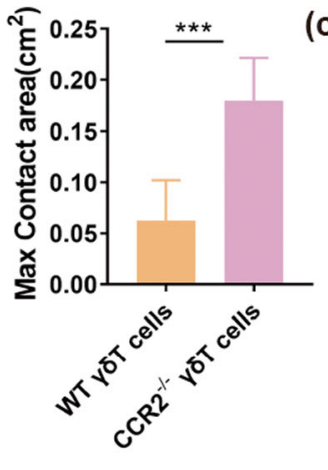

WT YoT cells CCR2 ${ }^{-1}$ -

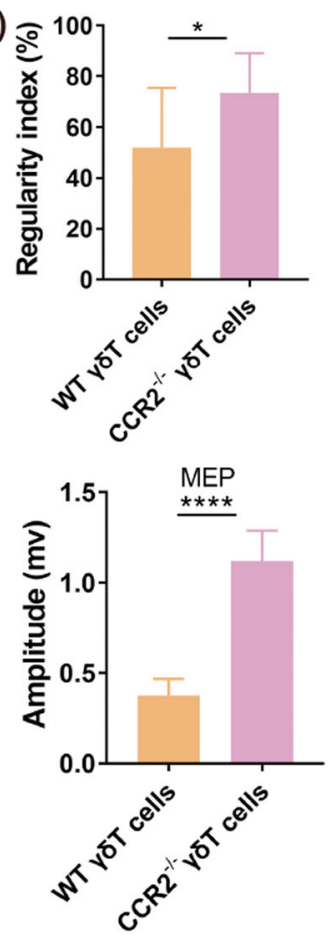

(f)

DAPI

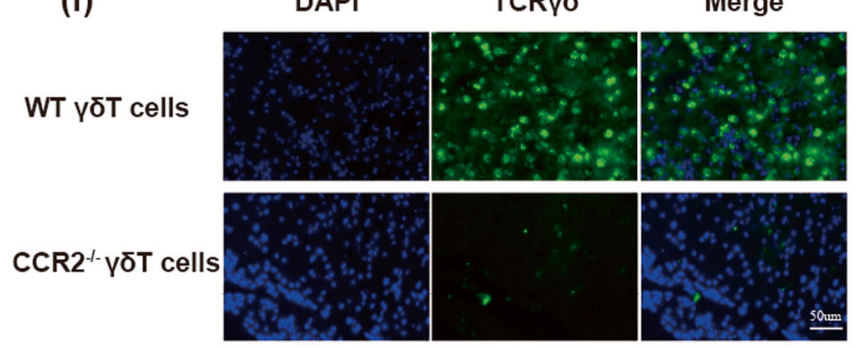

(g)
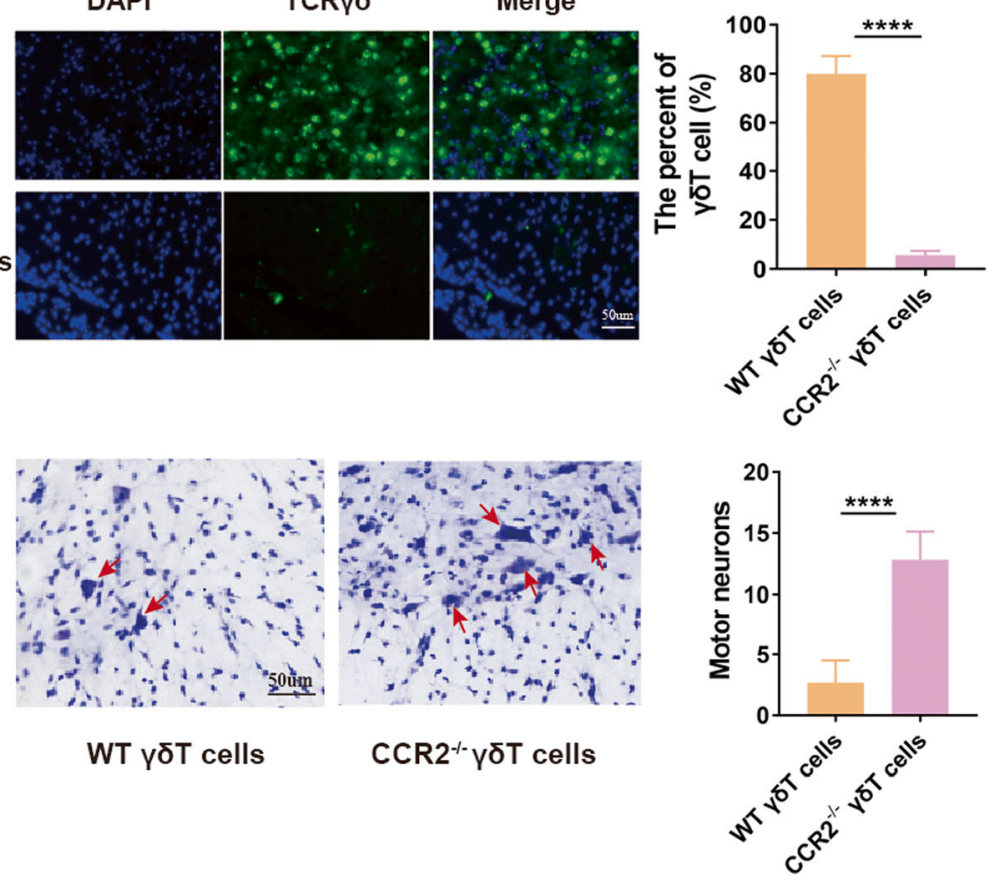

Fig. $7 \mathrm{TCR}^{-/-}$mice were reconstituted with $\gamma \delta \mathrm{T}$ cells from CCR2 $2^{-/-}$and WT mice. a BMS score of WT and CCR2 $2^{-/} \gamma \delta \mathrm{T}$ cells reconstituted mice at different time points after spinal cord injury (SCl) $\left(n=8\right.$ mice/per group). $\mathbf{b}$ Max contact area of WT and CCR2 ${ }^{-/} \gamma \delta$ T cells reconstituted mice at 6 wk after SCI ( $n=8$ mice/per group). c Regularity index of WT and CCR2 ${ }^{-1-} \gamma \delta$ T cells reconstituted mice at 6 weeks after SCI $(n=8$ mice/per group). $\mathbf{d}$ Cadence of WT and CCR2 ${ }^{-/-} \gamma \delta$ T cells reconstituted mice at $6 \mathrm{wk}$ after SCI ( $n=8$ mice/per group). e Motor-evoked potential (MEP) recordings from WT and CCR2 ${ }^{-1-} \gamma \delta$ T cells reconstituted mice at 6 weeks post-surgery ( $n=8$ mice/per group). $\mathbf{f}$ Spinal sections from WT and $\mathrm{CCR}^{-/-} \gamma \delta$ T cells reconstituted mice after 1 day post-SCI were immunostained with anti-TCRү $\delta$ (green, a maker for $\gamma \delta \mathrm{T}$ cell) and the corresponding static histogram of percent of $\gamma \delta$ T cell ( $\gamma \delta$ T cell/total cell) $(n=6$ mice/per group). $\mathbf{g}$ Survival of motor neurons immunostained with Nissl staining in cross-section of lesion epicenter at 6 weeks after $\mathrm{SCl}\left(n=6\right.$ mice/per group). ${ }^{*} P<0.05 ;{ }^{* *} P<0.01$; ${ }^{* * *} P<0.001$; ${ }^{* * * *} P$ $<0.0001$ 
(a)

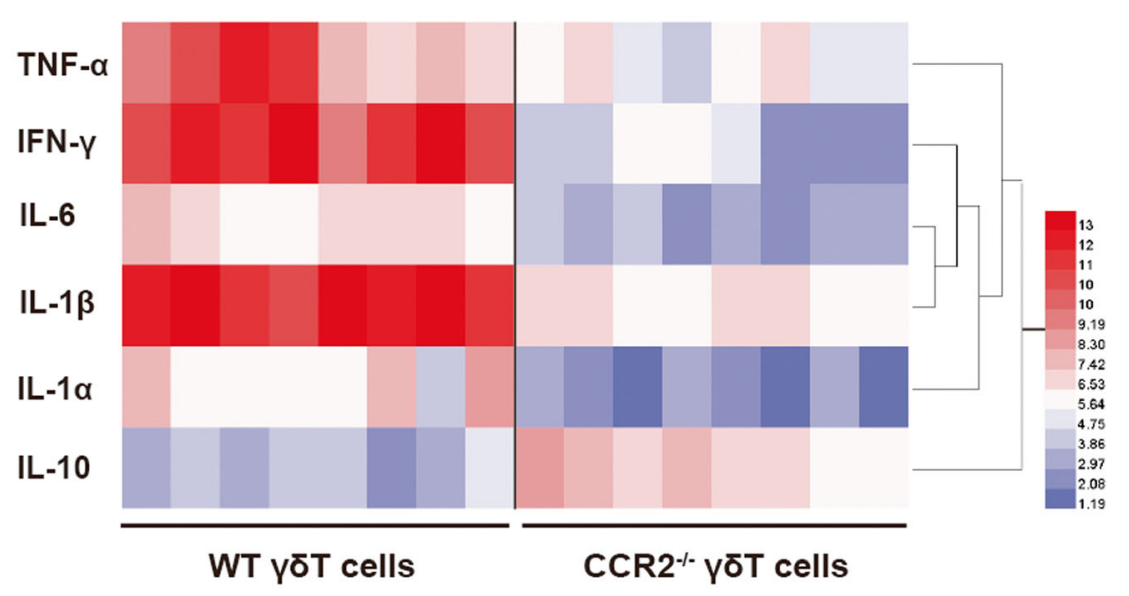

(b)
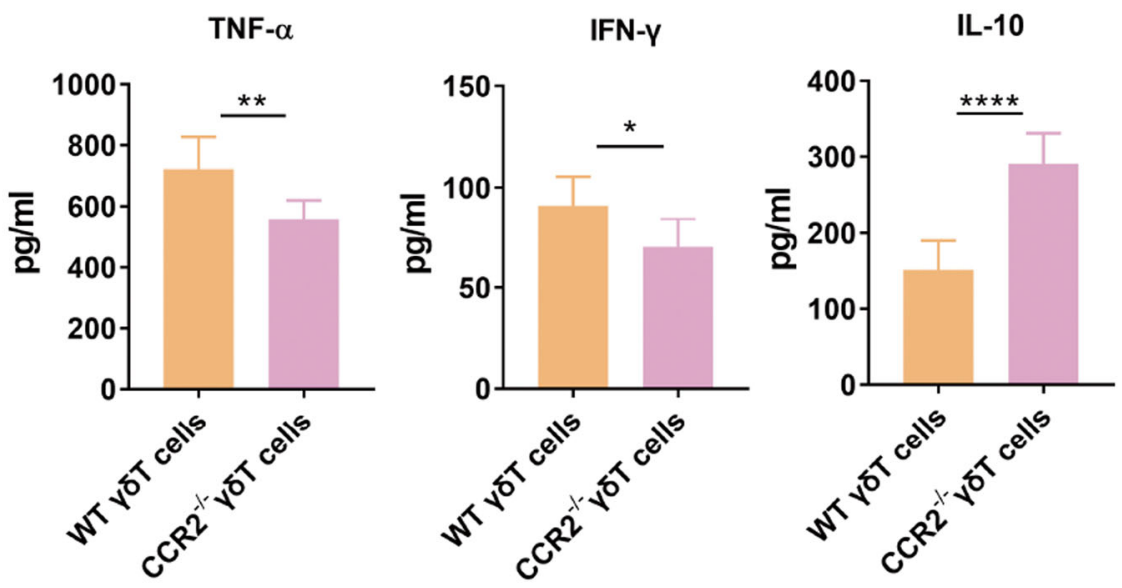

IL-6

IL-1 $\beta$

$\mathrm{IL}-1 \alpha$
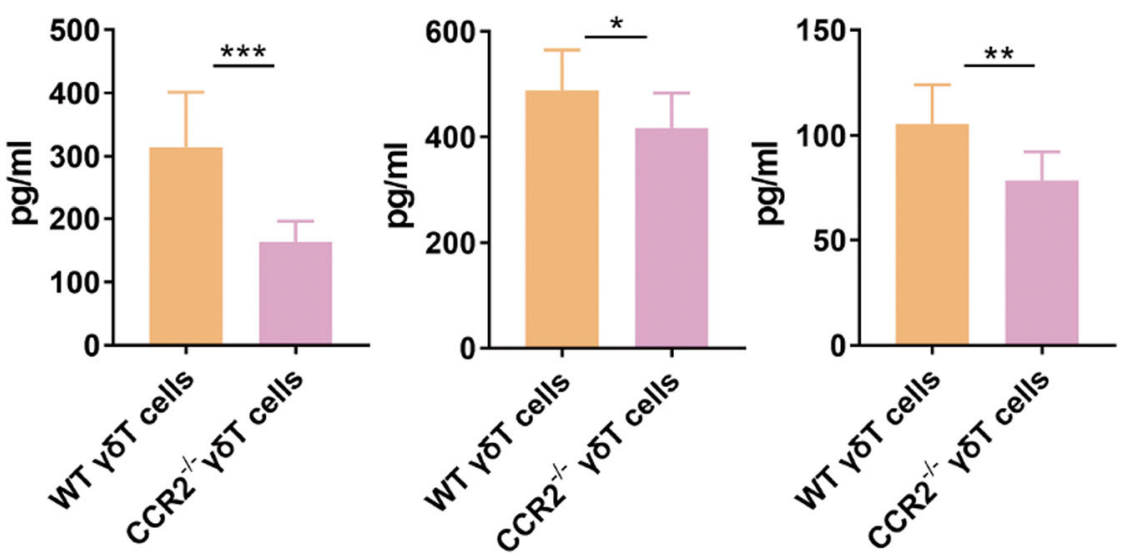

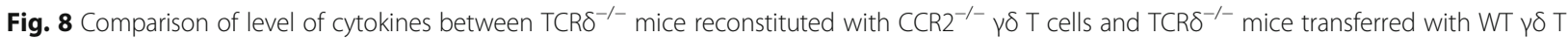
cells at 1 day post-spinal cord injury (SCl). a Luminex analysis system (Bio-Rad, Hercules, $\mathrm{CA}$ ) was used to analyze inflammatory protein level in spinal cord tissues at 1 day after SCI ( $n=8$ mice/per group). Different colors from low (blue) to high (red) represented the protein expression level (fold change). b Compared to WT $\gamma \delta$ T cells reconstituted group, pro-inflammatory cytokines including TNF-a, IFN- $\gamma$, IL-1 3 , IL-1a, and IL-6, were significantly down-regulated and anti-inflammatory IL-10 was upregulated in CCR2 ${ }^{-/-} \gamma \delta$ T cells transferred group ( $n=8$ mice/per group). ${ }^{*} P<0.05 ;{ }^{* *} P<0.01$; ${ }^{* * *} P<0.001$; ${ }^{* * * *} P<0.0001$ 
induced recruitment of $\gamma \delta$ T cells to injury site, we performed a comprehensive experimental comparison between $\mathrm{CCL}_{2}{ }^{-/-}$or $\mathrm{CCR}_{2}{ }^{--}$mice and WT mice. Our results showed that compared to WT mice, $\gamma \delta$ T cell recruitment to the SCI site was significantly reduced, and improvement of neurological function was obviously enhanced in CCL2 $2^{-1-}$ and $\mathrm{CCR} 2^{-1-}$ mouse models. This revealed that CCL2/CCR2 signaling plays a key role in the recruitment of $\gamma \delta \mathrm{T}$ cells to SCI site, and blocking of CCL2/CCR2 axis contributes to recovery of hind motor function. Therefore, the CCL2/CCR2 signaling may be considered a potential therapeutic target to prevent progression of SCI.

Previous several studies indicated that CCL2/CCR2 may be mainly associated with the neuroinflammatory response to the primary injury, and early production of chemokines after SCI that precedes the invasion of neutrophils, monocytes, and $\mathrm{T}$ cells into the injury spinal cord thereby mediating inflammatory development within the lesion cord site as a recruitment mechanism of circulating immune cells [35-37]. Furthermore, neuroinflammation leads to secondary injury and decreased recovery of neurological function after SCI. Taken together, CCL2/CCR2 signaling probably play an important role in recovery procession of neurological function after SCI. In this study, our results indicated that CCL2/ CCR2 signaling mediated the recruitment of $\gamma \delta \mathrm{T}$ cells to injury site, and $\gamma \delta \mathrm{T}$ cell recruitment to SCI site promotes inflammatory response and exacerbates neurological impairment.

$\gamma \delta \mathrm{T}$ cells can be classified as either IFN- $\gamma$ or IL-17 producers according to their biological characteristics [38]. IL17 is a key cytokine that regulates inflammatory progress, and serves as a communication bridge between immune cells and tissues [39]. Previous evidence demonstrated that the level of IL-17 was elevated after SCI, thus promoting an inflammatory response, enlarging the area of lesions, and further weakening neurological recovery [40]. However, IL17 does not directly activate astrocytes that secrete amounts of pro-inflammation cytokines, but does through synergistic effects with other cytokines such as IL-6 and TNF- $\alpha$ [41]. Additionally, our results showed that large numbers of $\gamma \delta$ $\mathrm{T}$ cells were recruited at SCI site, which aggravated the inflammatory response and hampered motor function improvement. Taken together, we made an initial conclusion that $\gamma \delta \mathrm{T}$ cell recruitment to SCI site may produce amounts of IL-17 that promote progression of neuroinflammation and block improvement of neurological functions. However, further studies should be performed to confirm this conclusion.

\section{Conclusions}

In general, as shown in our results, $\gamma \delta \mathrm{T}$ cell recruitment to SCI site promotes inflammatory response and exacerbates neurological impairment. Furthermore, CCL2/CCR2 signaling is a key recruitment mechanism of $\gamma \delta \mathrm{T}$ cells to injury site and may be a potential treatment target for future SCI.

\begin{abstract}
Abbreviations
SCl: Spinal cord injury; CCL2: C-C motif chemokine ligand 2; CCR2: C-C chemokine receptor type 2; ELISA: Enzyme-linked immunosorbent assays; PFA: Paraformaldehyde; CSF: Cerebrospinal fluid; QRT-PCR: Quantitative realtime polymerase chain reaction; MEPs: Motor-evoked potential testing; MACS: Magnetic-activated cell sorting; SD: Standard difference;

SEM: Standard error of mean; BMS: Basso Mouse Scale; EAE: Experimental autoimmune encephalomyelitis
\end{abstract}

\section{Supplementary Information}

The online version contains supplementary material available at https://doi. org/10.1186/s12974-021-02115-0.

\section{Additional file 1.}

Acknowledgements

Not applicable.

Authors' contributions

PX, WCZ, and GDS contributed to the conception, design, and writing of the manuscript. FZ, MMC, CZ, and CHS supported several experiments and contributed to the acquisition, analysis, and interpretation of data. HRZ, JCY, and ZZL contributed to the statistical analysis and revision of the manuscript. STL and GDS contributed to the technical support, conception and design, and revision of the manuscript. All authors read and approved the final manuscript.

\section{Funding}

This study was supported by grants from the National Natural Science Foundation of China (No. 31970862), the Natural Science Foundation of Guangdong Province (No. 2018A030313576, 2019A1515011335), the Science and Technology Program of Guangzhou (No. 201803010001), and Medical Scientific Research Foundation of Guangdong Province of China (No. A2019217).

Availability of data and materials

All the datasets and materials supporting the conclusions of this article are presented in the manuscript.

\section{Declarations}

\section{Ethics approval and consent to participate}

All experimental protocols in this study were approved by the Animals Care Committee of the University of Jinan. The experimental measurement on patients' CSF was approved by patients and Human Ethics Committee of Jinan University First Affiliated Hospital.

Consent for publication

All authors agree with the publication of the manuscript.

\section{Competing interests}

The authors declare that they have no competing interest.

\section{Author details}

${ }^{1}$ Department of Orthopedics, The First Affiliated Hospital of Jinan University, 601 West Whampoa Avenue, Guangzhou 510000, China. Intensive Care Unit, First Affiliated Hospital, Jinan University, Guangzhou, China. ${ }^{3}$ College of Traditional Chinese Medicine, Jinan University, Guangzhou, China. ${ }^{4}$ Department of Orthopedics, The Affiliated Jiangmen Traditional Chinese Medicine Hospital of Jinan University, Jiangmen, China. ${ }^{5}$ State Key Laboratory of Generic Manufacture Technology of Chinese Traditional Medicine, Lunan Pharmaceutical Group Co. Ltd., Linyi, China. ${ }^{6}$ Heyuan Affiliated Hospital of Jinan University, 733 Wenxiang Road, Heyuan 517000, China. ${ }^{7}$ Department of 
Pediatrics, The Sixth Affiliated Hospital, Sun Yat-sen University, No. 26 Yuancun Erheng Road, Tianhe District, Guangzhou 510655, China.

\section{Received: 19 December 2020 Accepted: 16 February 2021} Published online: 02 March 2021

\section{References}

1. Badhiwala JH, Wilson JR, Fehlings MG. Global burden of traumatic brain and spinal cord injury. Lancet Neurol. 2019;18(1):24-5. https://doi.org/10.1016/ S1474-4422(18)30444-7.

2. Rubiano AM, Carney N, Chesnut R, Puyana JC. Global neurotrauma research challenges and opportunities. Nature. 2015;527(7578):S193-7. https://doi. org/10.1038/nature16035.

3. Ahuja CS, Martin AR, Fehlings M. Recent advances in managing a spinal cord injury secondary to trauma. F1000Res. 2016;5:F1000. https://doi.org/1 0.12688/f1000research.7586.1 Faculty Rev-1017.

4. Sun G, Yang $\mathrm{S}$, Cao G, Wang Q, Hao J, Wen Q, et al. $\gamma \delta$ T cells provide the early source of IFN- $\gamma$ to aggravate lesions in spinal cord injury. J Exp Med. 2018;215(2):521-35. https://doi.org/10.1084/jem.20170686.

5. Morales II, Toscano-Tejeida D, Ibarra A. Non pharmacological strategies to promote spinal cord regeneration: a view on some individual or combined approaches. Curr Pharm Des. 2016;22(6):720-7. https://doi.org/10.2174/1381 612822666151204001103.

6. Paul S, Shilpi, Lal G. Role of gamma-delta ( $\gamma \delta)$ T cells in autoimmunity. J Leukoc Biol. 2015;97(2):259-71. https://doi.org/10.1189/jlb.3RU0914-443R.

7. Wo J, Zhang F, Li Z, Sun C, Zhang W, Sun G. The role of gamma-delta T cells in diseases of the central nervous system. Front Immunol. 2020;11: 580304. https://doi.org/10.3389/fimmu.2020.580304.

8. Zhong Q, Zhou K, Liang QL, Lin S, Wang YC, Xiong XY, et al. Interleukin-23 secreted by activated macrophages drives $\gamma \delta T$ cell production of interleukin-17 to aggravate secondary injury after intracerebral hemorrhage. J Am Heart Assoc. 2016;5(10):e004340. https://doi.org/10.1161/JAHA.116. 004340

9. Weber KS, von Hundelshausen P, Clark-Lewis I, Weber PC, Weber C. Differential immobilization and hierarchical involvement of chemokines in monocyte arrest and transmigration on inflamed endothelium in shear flow. Eur J Immunol. 1999;29(2):700-12. https://doi.org/10.1002/(SICI)1521-4141 (199902)29:02<700::AID-IMMU700>3.0.CO;2-1.

10. Morganti JM, Jopson TD, Liu S, Riparip LK, Guandique CK, et al. CCR2 antagonism alters brain macrophage polarization and ameliorates cognitive dysfunction induced by traumatic brain injury. J Neurosci. 2015;35(2):748-60. https://doi.org/10.1523/JNEUROSCI.2405-14.2015.

11. McKenzie DR, Kara EE, Bastow CR, Tyllis TS, Fenix KA, et al. IL-17-producing $\gamma \delta T$ cells switch migratory patterns between resting and activated states. Nat Commun. 2017;8:15632. https://doi.org/10.1038/ncomms15632.

12. Gray EE, Ramírez-Valle F, Xu Y, Wu S, Wu Z, et al. Deficiency in IL-17committed $V \gamma 4(+) \gamma \delta$ T cells in a spontaneous Sox13-mutant CD45.1(+) congenic mouse substrain provides protection from dermatitis. Nat Immunol. 2013;14(6):584-92. https://doi.org/10.1038/ni.2585.

13. Ramírez-Valle F, Gray EE, Cyster JG. Inflammation induces dermal Vy4+ үठT17 memory-like cells that travel to distant skin and accelerate secondary IL-17-driven responses. Proc Natl Acad Sci U S A. 2015;112(26):8046-51. https://doi.org/10.1073/pnas.1508990112.

14. Kara EE, McKenzie DR, Bastow CR, Gregor CE, Fenix KA, et al. CCR2 defines in vivo development and homing of IL-23-driven GM-CSF-producing Th17 cells. Nat Commun. 2015;6:8644. doi: https://doi.org/10.1038/ncomms9644.

15. Ma SF, Chen YJ, Zhang JX, Shen L, Wang R, et al. Adoptive transfer of M2 macrophages promotes locomotor recovery in adult rats after spinal cord injury. Brain Behav Immun. 2015;45:157-70. https://doi.org/10.1016/j.bbi.2 014.11.007.

16. Zhao R, Liu Y, Wang H, Yang J, Niu W, et al. BRD7 plays an antiinflammatory role during early acute inflammation by inhibiting activation of the NF-KB signaling pathway. Cell Mol Immunol. 2017;14(10):830-41. https://doi.org/10.1038/cmi.2016.31.

17. Basso DM, Fisher LC, Anderson AJ, Jakeman LB, McTique DM, et al. Basso Mouse Scale for locomotion detects differences in recovery after spinal cord injury in five common mouse strains. J Neurotrauma. 2006;23(5):635-59. https://doi.org/10.1089/neu.2006.23.635.

18. Koopmans GC, Deumens R, Honig WM, Hamers FP, Steinbusch HW, et al. The assessment of locomotor function in spinal cord injured rats: the importance of objective analysis of coordination. J Neurotrauma. 2005;22(2): 214-25. https://doi.org/10.1089/neu.2005.22.214.

19. Ding Y, Qu Y, Feng J, Wang M, Han Q, et al. Functional motor recovery from motoneuron axotomy is compromised in mice with defective corticospinal projections. PLoS One. 2014;9(7):e101918. https://doi.org/10.1371/journal. pone.0101918.

20. Hao J, Dong $S$, Xia $S$, He W, Jia $H$, et al. Regulatory role of $V_{Y} 1 \gamma^{\delta}$ T cells in tumor immunity through IL-4 production. J Immunol. 2011;187(10):4979-86. https://doi.org/10.4049/jimmunol.1101389.

21. He W, Hao J, Dong S, Gao Y, Tao J, et al. Naturally activated V gamma 4 gamma delta $T$ cells play a protective role in tumor immunity through expression of eomesodermin. J Immunol. 2010;185(1):126-33. https://doi. org/10.4049/jimmunol.0903767.

22. Zhao N, Hao J, Ni Y, Luo W, Liang R, et al. Vy4 $\gamma \delta$ T cell-derived IL-17A negatively regulates NKT cell function in Con A-induced fulminant hepatitis. J Immunol. 2011;187(10):5007-14. https://doi.org/10.4049/jimmunol.1101315.

23. Fleming JC, Norenberg MD, Ramsay DA, Dekaban GA, Marcillo AE, et al. The cellular inflammatory response in human spinal cords after injury. Brain. 2006;129(Pt 12):3249-69. https://doi.org/10.1093/brain/awl296.

24. Shiromizu CM, Jancic CC. $\gamma \delta$ T lymphocytes: an effector cell in autoimmunity and infection. Front Immunol. 2018:9:2389. https://doi.org/1 0.3389/fimmu.2018.02389.

25. McGinley AM, Edwards SC, Raverdeau M, Mills KHG. Th17 cells, $\gamma \delta$ T cells and their interplay in EAE and multiple sclerosis. J Autoimmun. 2018:508968411(18)30007-6. https://doi.org/10.1016/j.jaut.2018.01.001.

26. Gao Y, Yang W, Pan M, Scully E, Girardi M, et al. Gamma delta T cells provide an early source of interferon gamma in tumor immunity. J Exp Med. 2003;198(3):433-42. https://doi.org/10.1084/jem.20030584.

27. Daley $D$, Zambirinis $C P$, Seifert L, Akkad N, Mohan N, et al. $\gamma \delta$ T cells support pancreatic oncogenesis by restraining a $\mathrm{\beta}$ T cell activation. Cell. 2016;166(6): 1485-1499.e15. https://doi.org/10.1016/j.cell.2016.07.046.

28. O'Connor T, Borsig L, Heikenwalder M. CCL2-CCR2 signaling in disease pathogenesis. Endocr Metab Immune Disord Drug Targets. 2015;15(2):10518. https://doi.org/10.2174/1871530315666150316120920.

29. He M, Dong H, Huang Y, Lu S, Zhang S, et al. Astrocyte-derived CCL2 is associated with $\mathrm{M} 1$ activation and recruitment of cultured microglial cells. Cell Physiol Biochem. 2016;38(3):859-70. https://doi.org/10.1159/000443040.

30. Xu J, Dong H, Qian Q, Zhang X, Wang Y, et al. Astrocyte-derived CCL2 participates in surgery-induced cognitive dysfunction and neuroinflammation via evoking microglia activation. Behav Brain Res. 2017; 332:145-53. https://doi.org/10.1016/j.bbr.2017.05.066.

31. Moreno M, Bannerman P, Ma J, Guo F, Miers L, et al. Conditional ablation of astroglial CCL2 suppresses CNS accumulation of M1 macrophages and preserves axons in mice with MOG peptide EAE. J Neurosci. 2014;34(24): 8175-85. https://doi.org/10.1523/JNEUROSCI.1137-14.2014.

32. Shih YT, Wang MC, Zhou J, Peng HH, Lee DY, et al. Endothelial progenitors promote hepatocarcinoma intrahepatic metastasis through monocyte chemotactic protein-1 induction of microRNA-21. Gut. 2015;64(7):1132-47. https://doi.org/10.1136/gutjnl-2013-306302.

33. Hsieh CL, Niemi EC, Wang SH, Lee CC, Bingham D, et al. CCR2 deficiency impairs macrophage infiltration and improves cognitive function after traumatic brain injury. J Neurotrauma. 2014;31(20):1677-88. https://doi.org/1 0.1089/neu.2013.3252.

34. Hammond MD, Taylor RA, Mullen MT, Ai Y, Aguila HL, et al. CCR2+ Ly6C(hi) inflammatory monocyte recruitment exacerbates acute disability following intracerebral hemorrhage. J Neurosci. 2014;34(11):3901-9. https://doi.org/1 0.1523/JNEUROSCI.4070-13.2014.

35. McTigue DM, Tani M, Krivacic K, Chernosky A, Kelner GS, et al. Selective chemokine mRNA accumulation in the rat spinal cord after contusion injury. J Neurosci Res. 1998:53(3):368-76. https://doi.org/10.1002/(SICI) 1097-4547(1 9980801)53:3<368::AID-JNR11>3.0.CO;2-1.

36. Glabinski AR, Bielecki B, O'Bryant S, Selmaj K, Ransohoff RM. Experimental autoimmune encephalomyelitis: CC chemokine receptor expression by trafficking cells. J Autoimmun. 2002;19(4):175-81. https://doi.org/10.1006/ja ut.2002.0613.

37. Zhang $\mathrm{N}$, Inan $\mathrm{S}$, Cowan $\mathrm{A}$, Sun $\mathrm{R}$, Wang JM, et al. A proinflammatory chemokine, CCL3, sensitizes the heat- and capsaicin-gated ion channel TRPV1. Proc Natl Acad Sci USA. 2005;102(12):4536-41. https://doi.org/10.1 073/pnas.0406030102.

38. Schmolka N, Wencker M, Hayday AC, Silva-Santos B. Epigenetic and transcriptional regulation of $\gamma \delta \mathrm{T}$ cell differentiation: programming cells for 
responses in time and space. Semin Immunol. 2015;27(1):19-25. https://doi. org/10.1016/j.smim.2015.01.001.

39. Gelderblom M, Weymar A, Bernreuther C, Velden J, Arunachalam P, et al. Neutralization of the IL-17 axis diminishes neutrophil invasion and protects from ischemic stroke. Blood. 2012;120(18):3793-802. https://doi.org/10.1182/ blood-2012-02-412726.

40. You T, Bi Y, Li J, Zhang M, Chen $X$, et al. IL-17 induces reactive astrocytes and up-regulation of vascular endothelial growth factor (VEGF) through JAK/STAT signaling. Sci Rep. 2017;7:41779. https://doi.org/10.1038/srep41 779.

41. Ma X, Reynolds SL, Baker BJ, Li X, Benveniste EN, et al. IL-17 enhancement of the IL-6 signaling cascade in astrocytes. J Immunol. 2010;184(9):4898-906. https://doi.org/10.4049/jimmunol.1000142.

\section{Publisher's Note}

Springer Nature remains neutral with regard to jurisdictional claims in published maps and institutional affiliations.

Ready to submit your research? Choose BMC and benefit from:

- fast, convenient online submission

- thorough peer review by experienced researchers in your field

- rapid publication on acceptance

- support for research data, including large and complex data types

- gold Open Access which fosters wider collaboration and increased citations

- maximum visibility for your research: over $100 \mathrm{M}$ website views per year

At BMC, research is always in progress.

Learn more biomedcentral.com/submissions 